\title{
X-Ray and NMR Study of the Structural Features of SCS-Pincer Metal Complexes of the Group 10 Triad
}

\author{
Cornelis A. Kruithof, ${ }^{\dagger}$ Harmen P. Dijkstra, ${ }^{\dagger}$ Martin Lutz, ${ }^{\ddagger}$ Anthony L. Spek, ${ }^{\ddagger}$ \\ Robertus J. M. Klein Gebbink, ${ }^{* \dagger}$ and Gerard van Koten* ${ }^{* \dagger}$ \\ Chemical Biology and Organic Chemistry, Debye Institute for NanoMaterials Science, Faculty of Science, \\ Utrecht University, Padualaan 8, 3584 CH, Utrecht, The Netherlands, and Crystal and Structural \\ Chemistry, Bijvoet Center for Biomolecular Research, Faculty of Science, Utrecht University, \\ Padualaan 8, $3584 \mathrm{CH}$ Utrecht, The Netherlands
}

Received April 10, 2008

\begin{abstract}
SCS-pincer metal complexes $[\mathrm{MX}(\mathrm{SCS})]\left(\mathrm{SCS}=\left[2,6-\left(\mathrm{RSCH}_{2}\right)_{2} \mathrm{C}_{6} \mathrm{H}_{3}\right]^{-} ; \mathrm{R}=\mathrm{Ph}:{ }^{\mathrm{Ph}} \mathrm{SCS} ; \mathrm{R}=\mathrm{Me}\right.$ : ${ }^{\mathrm{Me}} \mathrm{SCS} ; \mathrm{M}=\mathrm{Pd}, \mathrm{Pt}, \mathrm{Ni}$ ) have been synthesized via mild and tolerant oxidative addition procedures. The complexes have been characterized by ${ }^{1} \mathrm{H}$ and ${ }^{13} \mathrm{C}$ NMR spectroscopy and X-ray crystal structure determination. Interestingly, the crystal structures of $\left[\mathrm{NiBr}\left({ }^{\mathrm{Me}} \mathrm{SCS}\right)\right] \mathbf{4},\left[\mathrm{PdBr}\left({ }^{\mathrm{Me}} \mathrm{SCS}\right)\right] \mathbf{5},\left[\mathrm{PtBr}\left({ }^{\mathrm{Me}} \mathrm{SCS}\right)\right]$ 6, and $\left[\mathrm{PtBr}\left({ }^{\mathrm{Ph}} \mathrm{SCS}\right)\right] 8$ each have a unit cell with a unique set of independent $\left[\mathrm{MBr}\left({ }^{\mathrm{R}} \mathrm{SCS}\right)\right]$ molecules; each of these structures has a different conformation of the five-membered ortho-chelate ring (including the configuration of the coordinated S-center) in the solid state. The temperature-dependent ${ }^{1} \mathrm{H}$ NMR resonance patterns of these complexes in solution were related to structural features encountered in the solid state and allowed us to assign all dynamic processes (rac/meso isomerizations) that occurred in solution.
\end{abstract}

\section{Introduction}

Since the first reports on organometallic complexes bearing the potentially terdentate, monoanionic ECE-pincer ligand ([2,6$\left.\left(\mathrm{ECH}_{2}\right)_{2} \mathrm{C}_{6} \mathrm{H}_{3}\right]^{-}, \mathrm{E}=\mathrm{SR}, \mathrm{NR}_{2}, \mathrm{PR}_{2}$, Figure 1) in the $1970 \mathrm{~s},{ }^{1}$ a large number of reports have appeared describing its intriguing properties. $^{2}$ One of the main features of ECE-pincer metal complexes is the chemical stability of the metal-to-carbon $\sigma$-bond, a characteristic feature that has prompted many studies with pincer complexes in a variety of areas. Examples include their use in mechanistic studies involving elementary steps in metal catalyzed reactions, ${ }^{2}$ synthetic catalytic applications, ${ }^{3}$

* To whom correspondence should be addressed. E-mail: r.j.m.kleingebbink@uu.nl; g.vankoten@uu.nl

Chemical Biology and Organic Chemistry.

₹rystal and Structural Chemistry, Bijvoet Center for Biomolecular Research.

(1) (a) Moulton, C. J.; Shaw, B. L. J. Chem. Soc., Dalton Trans. 1976, 1020. (b) van Koten, G.; Timmer, K.; Noltes, J. G.; Spek, A. L. J. Chem. Soc., Chem. Commun. 1978, 250, 252. (c) van Koten, G.; Jastrzebski, J. T. B. H.; Noltes, J. G.; Spek, A. L.; Schoone, J. C. J. Organomet. Chem. 1978, 148, 233-245. (d) Creaser, C. S.; Kaska, W. C. Inorg. Chim. Acta 1978, 30, L325-L326. (e) Rimml, H.; Venanzi, L. M. J. Organomet. Chem. 1983, 259, C6-C7. (f) Grove, D. M.; van Koten, G.; Ubbels, H. J. C.; Spek, A. L. J. Am. Chem. Soc. 1982, 104, 4285-4286. (g) Grove, D. M.; van Koten, G.; Louwen, J. N.; Noltes, J. G.; Spek, A. L.; Ubbels, H. J. C. J. Am. Chem. Soc. 1982, 104, 6609-6616. (h) Terheijden, J.; van Koten, G.; Vinke, I. C.; Spek, A. L. J. Am. Chem. Soc. 1985, 107, 2891-2898.

(2) (a) Albrecht, M.; van Koten, G. Angew. Chem., Int. Ed. 2001, 41, 3750-3781. (b) van der Boom, M. E.; Milstein, D. Chem. Rev. 2003, 103, 1759-1792. (c) Gossage, R. A.; van de Kuil, L. A.; van Koten, G. Acc. Chem. Res. 1998, 31, 423-431. (d) Rybtchinski, B.; Milstein, D. Angew. Chem., Int. Ed. 1999, 38, 871-883. See also special issue in: (e) Inorg. Chim. Acta 2006, 359 (6), 1701-1988.

(3) See, for example: (a) Singleton, J. T. Tetrahedron 2003, 59, 18371857. (b) Aydin, J.; Kumar, K. S.; Eriksson, L.; Szabo, K. J. Adv. Synth. Catal. 2007, 349, 2585. (c) Selander, N.; Kipke, A.; Sebelius, A.; Szabo, K. J. J. Am. Chem. Soc. 2007, 129, 13723. (d) Zhao, J.; Goldman, A. S.; Hartwig, J. F. Science 2005, 307, 1080-1082. (e) Goldman, A. S.; Roy, A. H.; Huang, Z.; Ahuja, R.; Schinski, W.; Brookhart, M. Science 2006, 312, 257-261. (f) Dijkstra, H. P.; Albrecht, M.; Medici, S.; van Klink, G. P. M.; van Koten, G. Adv. Synth. Catal. 2002, 344, 1135-1141. catalyst immobilization and recycling set-ups, ${ }^{4}$ materials science such as gas or metal sensor materials, ${ }^{2 \mathrm{~b}, 5}$ the synthesis of ECEpincer metal complexes ( $\mathrm{Li}, \mathrm{Au}, \mathrm{Pt}, \mathrm{Ru}$ complexes),${ }^{5-7}$ and the field of supramolecular chemistry. ${ }^{8}$ An important reason for the broad applicability of the ECE-pincer ligand system is the possibility to introduce a wide variety of transition metals. By virtue of the high chemical stability, alterations of the electronic environment of the metal can easily be accomplished by changing the nature of both the donor atoms (E) and its substituents (R). In addition, ancillary groups $(\mathrm{Z})^{9}$ have been introduced into the ligand system using straightforward synthetic methods, which also have significantly contributed to the wide

(4) (a) Dijkstra, H. P.; Kruithof, C. A.; Ronde, N.; van de Coevering, R.; Ramon, D. J.; Vogt, D.; van Klink, G. P. M.; van Koten, G. J. Org. Chem. 2003, 68, 675. (b) Dijkstra, H. P.; Ronde, N.; Vogt, D.; van Klink, G. P. M.; van Koten, G. Adv. Synth. Catal. 2003, 345, 364. (c) Kleij, A. W.; Gossage, R. A.; Jastrzebski, J. T. B. H.; Boersma, J.; van Koten, G. Angew. Chem., Int. Ed. 2000, 39, 176.

(5) Gossage, R. A.; Jastrzebski, J. T. B. H.; van Koten, G. Angew. Chem., Int. Ed. 2005, 44, 1448-1454.

(6) Contel, M.; Stol, M.; Casado, M. A.; van Klink, G. P. M.; Ellis, D. D.; Spek, A. L.; van Koten, G. Organometallics 2002, 21, 4556-4559.

(7) (a) Suijkerbuijk, B. M. J. M.; Lutz, M.; Spek, A. L.; van Koten, G; Klein Gebbink, R. J. M. Org. Lett. 2004, 6, 3023-3026. (b) Dani, P.; Karlen, T.; Gossage, R. A.; Smeets, W. J. J.; Spek, A. L.; van Koten, G. J. Am. Chem. Soc. 1997, 119, 11317-11318. (c) Albrecht, M.; Dani, P.; Lutz, M.; Spek, A. L.; van Koten, G. J. Am. Chem. Soc. 2000, 122, 11822-11833. (d) Dijkstra, H. P.; Albrecht, M.; van Koten, G. Chem. Commun. 2002, $126-127$.

(8) (a) South, C. R.; Higley, Mary N.; Leung, K. C.-F.; Lanari, D.; Nelson, A.; Grubbs, R. H.; Stoddart, J. F.; Weck, M. Chem.-Eur. J. 2006, 12, 3789-3797. (b) Yount, W. C.; Loveless, D. M.; Craig, S. L. Angew. Chem., Int. Ed. 2005, 44, 2746-2748. (c) Stiriba, S.-E.; Slagt, M. Q.; Kautz, H.; Klein Gebbink, R. J. M.; Thomann, R.; Frey, H.; van Koten, G. Chem.Eur. J. 2004, 10, 1267-1273. (d) Pollino, J. M.; Weck, M. Synthesis 2002, 9, 1277-1285. (e) van Manen, H.-J.; Auletta, T.; Dordi, B.; Schonherr, H.; Vancso, G. J.; van Veggel, F. C. J. M.; Reinhoudt, D. N. Adv. Funct. Mat. 2002, 12, 811-818.

(9) (a) Wayne, C. Y.; Hemraj, J.; Craig, S. L. J. Am. Chem. Soc. 2003, 125, 15302-15303. (b) Chuchuryukin, A. V.; Chase, P. A.; Mills, A. M.; Lutz, M.; Spek, A. L.; van Klink, G. P. M.; van Koten, G. Inorg. Chem. 2006, 45, 2045-2054. 


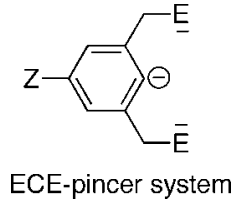

Figure 1. Potentially six electron-donating (three electron pairs) monoanionic ECE-pincer system. $\mathrm{E}=$ for example, $\mathrm{PR}_{2}(\mathrm{PCP})$, $\mathrm{SR}$ (SCS), $\mathrm{NR}_{2}(\mathrm{NCN}) ; \mathrm{Z}=$ ancillary group.

applicability of pincer metal complexes. For example, $\mathrm{Z}$ was used to fine-tune the electronic configuration of the pincer metal center ${ }^{10}$ or to anchor pincer catalysts to supports for catalyst recycling purposes. ${ }^{4}$

Recent research efforts in our group involve the covalent attachment of SCS-pincer metal- $\mathrm{d}^{8}$ complexes to the active site of a lipase using an active site-directed anchoring protocol. ${ }^{11}$ This was achieved by functionalization of the complexes with an inhibitory active phosphonate probe via a robust 1,3propanediyl tether (Scheme 1). Pincer metal- $\mathrm{d}^{8}$ complexes were chosen because they are stable and relatively small and should therefore be accommodated suitably by the active site of enzymes. Moreover, they are multifunctional and have, for example, proven to be good catalysts using solely a basic aqueous solution as solvent. ${ }^{12}$ In the course of our studies, we realized that common SCS-pincer metalation procedures, for example, by $\mathrm{CH}$ activation methods of the corresponding $\mathrm{SCS}(\mathrm{H})$ arene ligand, ${ }^{13}$ were incompatible with the phosphonate functionality attached to the SCS-pincer arene ligands. In addition, also for the incorporation of SCS-metal complexes in multimetallic materials, for example, metallodendrimers or pincer functionalized porphyrins, ${ }^{14}$ milder and high yielding

(10) (a) van de Kuil, L. A.; Grove, D. M.; Gossage, R. A.; Zwikker, J. W.; Jenneskens, L. W.; Drenth, W.; van Koten, G. Organometallics 1997, 16, 4985. (b) Dijkstra, H. P.; Slagt, M. Q.; McDonald, A.; Kruithof, C. A.; Kreiter, R.; Mills, A. M.; Lutz, M.; Spek, A. L.; Klopper, W.; van Klink, G. P. M.; van Koten, G. Eur. J. Inorg. Chem. 2003, 830. (c) Slagt, M. Q.; Rodriguez, G.; Grutters, M. M. P.; Klein Gebbink, R. J. M.; Klopper, W.; Jenneskens, L. W.; Lutz, M.; Spek, A. L.; van Koten, G. Chem.-Eur. J. 2004, 10, 1331.

(11) Kruithof, C. A.; Casado, M. A.; Guillena, G.; Egmond, M. R.; van der Kerk-van Hoof, A.; Heck, A. J. R.; Klein Gebbink, R. J. M.; van Koten, G. Chem.-Eur. J. 2005, 11, 6869-6877.

(12) (a) Nakai, H.; Ogo, S.; Watanabe, Y. Organometallics 2002, 21, 1674-1678. (b) Ogo, S.; Takebe, Y.; Uehara, K.; Yamazaki, T.; Nakai, H.; Watanabe, Y.; Fukuzumi, S. Organometallic 2006, 25, 331-338.

(13) (a) Errington, J.; McDonald, W. S.; Shaw, B. L. J. Chem. Soc., Dalton Trans. 1980, 2312-2314. (b) Dupont, J.; Beydoun, N.; Pfeffer, M. J. Chem. Soc., Dalton Trans. 1989, 1715-1720. (c) Lucena, N.; Casabo, J.; Escriche, L.; Sanchez-Castello, G.; Teixidor, F.; Kivekas, R.; Sillanpaa, R. Polyhedron 1996, 15, 3009-3018. (d) Loeb, S. J.; Shimizu, G. K. H.; Wisner, J. A. Organometallics 1998, 17, 2324-2327. (e) van Manen, H. J.; Nakashima, K.; Shinkai, S.; Kooijman, H.; Spek, A. L.; van Veggel, F.; Reinhoudt, D. N. Eur. J. Inorg. Chem. 2000, 253, 3-2540. (f) Kickham, J. E.; Loeb, S. J. Inorg. Chem. 1994, 33, 4351-4359. (g) Kickham, J. E.; Loeb, S. J. Inorg. Chem. 1995, 34, 5656-5665. (h) Cameron, B. R.; Loeb, S. J.; Yap, G. P. A. Inorg. Chem. 1997, 36, 5498-5504. (i) Kickham, J. E.; Loeb, S. J.; Murphy, S. L. Chem.-Eur. J. 1997, 3, 1203-1213. (j) Loeb, S. J.; Shimizu, G. K. H. Chem. Commun. 1993, 1395-1397. (k) Huck, W. T. S.; van Veggel, F. C. J. M.; Kropman, B. L.; Blank, D. H. A.; Keim, E. G.; Smithers, M. M. A.; Reinhoudt, D. N. J. Am. Chem. Soc. 1995, 117, 8293-8294. (1) Huck, W. T. S.; Snellink-Ruel, B.; van Veggel, F.; Reinhoudt, D. N. Organometallics 1997, 16, 4287-4291. (m) Huck, W. T. S.; Prins, L. J.; Fokkens, R. H.; Nibbering, N. M. M.; van Veggel, F.; Reinhoudt, D. N. J. Am. Chem. Soc. 1998, 120, 6240-6246. (n) Basca, J; Moutloali, R. M.; Darkwa, J. Acta. Cryst. C 2002, C58, m109-m110.

(14) (a) Dijkstra, H. P.; Steenwinkel, P.; Grove, D. M.; Lutz, M.; Spek, A. L.; van Koten, G. Angew. Chem., Int. Ed. 1998, 38, 2185. (b) Suijkerbuijk, B. M. J. M.; Lutz, M.; Spek, A. L.; van Koten, G.; Klein Gebbink, R. J. M. Org. Lett. 2004, 6, 3023. (c) Huck, W. T. S.; Prins, L. J.; Fokkens, R. H.; Nibbering, N. M. N.; van Veggel, F. C. J. M.; Reinhoudt, D. N. J. Am. Chem. Soc. 1998, 120, 6240. metalation procedures are desirable. Accordingly, here we report milder metalation of SCS-pincer ligands via oxidative addition procedures, which resulted in the synthesis of a small series of SCS-pincer Pt- and Pd-complexes and also in the first example of a square planar SCS-pincer Ni-complex $\left[\mathrm{NiBr}\left({ }^{\mathrm{Me}} \mathrm{SCS}\right)\right]$.

Metalated SCS-pincer complexes are versatile materials and are often used as homogeneous (pre)catalysts ${ }^{15}$ or as building blocks in organometallic materials. ${ }^{14,16}$ For such applications, it is important to know and to understand the fluxional processes occurring around the metal center, as they will (partly) determine the outcome of the reactions. A preliminary study by Pfeffer and co-workers revealed that ${ }^{\mathrm{Me} S C S}$-pincer palladium complexes possess fluxional behavior in solution in which the stereochemistry on the chiral sulfur atoms can interconvert and that concurrent ring puckering inversion of the two metallacycles can occur. ${ }^{13 b}$ Such studies have not been performed with SCSplatinum and -nickel complexes. Consequently, we decided to study the fluxional behavior and stereochemical effects of the prepared SCS-pincer nickel(II), palladium(II), and platinum(II) complexes in greater detail both in solution (NMR spectroscopy) and in the solid state (X-ray diffraction). This allowed us to determine the influence of the metal center on these fluxional processes.

\section{Results and Discussion}

Syntheses of Ligands and Complexes. The reported metalation procedures for SCS-pincer arene ligands mainly rely on $\mathrm{C}-\mathrm{H}$ activation reactions of the arene ligand with cationic metal complexes. For the synthesis of SCS-pincer palladium complexes, mainly $\left[\mathrm{PdCl}_{2}(\mathrm{RCN})_{2}\right]$ or $\left[\mathrm{Pd}(\mathrm{RCN})_{4}\right]\left(\mathrm{BF}_{4}\right)_{2}(\mathrm{R}=\mathrm{Me}$, $\mathrm{Ph})$ as palladium source have been used. ${ }^{13}$ Whereas the syntheses of two platinum complexes (prepared by $\mathrm{CH}$ activation using $\left.\mathrm{PtCl}_{2}(\mathrm{COD})\right)^{17}$ and of various SCS-pincer palladium complexes have been described, the synthesis of the corresponding nickel complexes has to the best of our knowledge not been reported.

In general, oxidative addition reactions of suitable metal precursors to the $\mathrm{C}_{\mathrm{ipso}}$-halide bond of pincer ligands take place under very mild reaction conditions and are therefore desirable metalation routes when multiple or sensitive functionalities are present. This procedure is well documented for NCN-type ligands; ${ }^{2}$ however, it has never been applied to SCS-pincer bromide ligands. ${ }^{18-20}$ The required ligand syntheses are outlined in Scheme 2. The aryl halide substrates for this approach were

(15) (a) Bergbreiter, D. E.; Osburn, P. L.; Liu, Y.-S. J. Am. Chem. Soc. 1999, 121, 9531. (b) Sommer, W.; Yu, K.; Sears, J. S.; Ji, Y.; Zheng, X.; Davis, R. J.; Sherril, C. D.; Jones, C. W.; Weck, M. Organometallics 2005, 24, 4351. (c) Beletskaya, I. P.; Cheprakov, A. V. J. Organomet. Chem. 2004, 689, 4055

(16) (a) Amijs, C. H. M.; van Klink, G. P. M.; Lutz, M.; Spek, A. L.; van Koten, G. Organometallics 2005, 24, 2944. (b) Loeb, S. J.; Shimizu, G. K. H.; Wisner, J. A. Organometallics 2002, 21, 1674.

(17) Hanan, G. S.; Kickmam, J. E.; Loeb, S. J. Organometallics 1992, $11,3063-3068$.

(18) (a) Grove, D. M.; van Koten, G.; Mul, P.; Zoet, R.; van der Linden, J. G. M.; Legters, J.; Schmitz, J. E. J.; Murall, N. W.; Welch, A. J. Inorg. Chem. 1988, 27, 2466-2473. (b) van de Kuil, L. A.; Luitjes, H.; Grove, D. M.; Zwikker, J. W.; van der Linden, J. G. M.; Roelofsen, A. M.; Jenneskens, L. W.; Drenth, W.; van Koten, G. Organometallics 1994, 13, 468-477.

(19) Alsters, P. A.; Baesjou, P. J.; Janssen, M. D.; Kooijman, H.; Sicherer-Roetman, A.; Spek, A. L.; van Koten, G. Organometallics 1992, $11,4124-4135$.

(20) (a) Canty, A. J; Patel, J.; Skelton, B. W.; White, A. H. J. Organomet. Chem. 2000, 599, 195-199. (b) Rodriguez, G.; Albrecht, M.; Schoenmaker, J.; Ford, A.; Lutz, M.; Spek, A. L.; van Koten, G. J. Am. Chem. Soc. 2002, $124,5127-5138$. 
Scheme 1. ECE-Pincer Metal Complex Functionalized Phosphonates Inhibiting the Active Site of a Lipase ${ }^{11}$
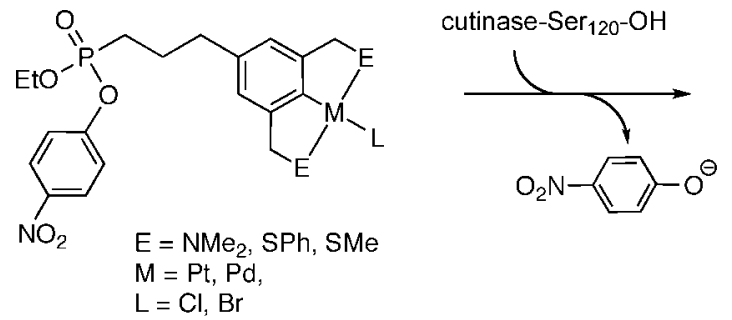

$\mathrm{M}=\mathrm{Pt}, \mathrm{Pd}$

$\mathrm{Cl}, \mathrm{Br}$

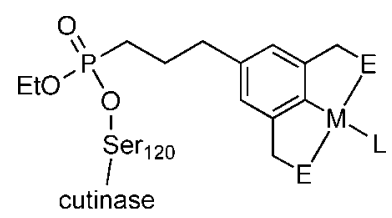

Scheme 2. Synthetic Procedure Applied for the Synthesis of ${ }^{\mathrm{R}}$ SCS-Pincer Metal Complexes ${ }^{a}$

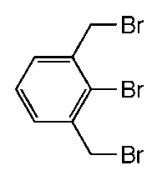

1
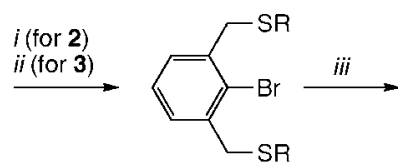

$2 \mathrm{R}=\mathrm{Me}$
$3 \mathrm{R}=\mathrm{Ph}$

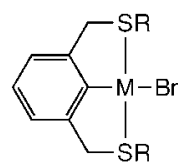

$4 \mathrm{R}=\mathrm{Me} \mathrm{M}=\mathrm{Ni}$ $5 \mathrm{R}=\mathrm{Me} \mathrm{M}=\mathrm{Pd}$ $6 \mathrm{R}=\mathrm{Me} M=\mathrm{Pt}$ $7 \mathrm{R}=\mathrm{PhM}=\mathrm{Pd}$ $8 \mathrm{R}=\mathrm{PhM}=\mathrm{Pt}$

${ }^{a}$ Reaction conditions: (i) NaSMe, RT, 16 h, THF; (ii) Thiophenol, $\mathrm{K}_{2} \mathrm{CO}_{3}, 18$-crown-6, RT, $16 \mathrm{~h}, \mathrm{Et}_{2} \mathrm{O}$; (iii) $\left[\mathrm{Ni}(\mathrm{COD})_{2}\right],-80{ }^{\circ} \mathrm{C} \rightarrow \mathrm{RT}$, $16 \mathrm{~h}$, THF or $\left[\mathrm{Pd}_{2} \mathrm{dba}_{3}\right] \cdot \mathrm{CHCl}_{3}, \mathrm{RT}, 16 \mathrm{~h}, \mathrm{C}_{6} \mathrm{H}_{6}$ or $\left[\left\{\mathrm{Pt}(p \text {-tol })_{2}(\mu\right.\right.$ $\left.\left.\left.\mathrm{SEt}_{2}\right)\right\}_{2}\right]$, reflux, $1 \mathrm{~h}, \mathrm{C}_{6} \mathrm{H}_{6}$.

prepared by reacting bis(benzylic bromide) $\mathbf{1}^{21}$ with $\mathrm{NaSMe}$ (for 2) or with thiophenol in the presence of $\mathrm{K}_{2} \mathrm{CO}_{3}$ and 18-crown-6 (for 3, Scheme 2). Both reactions were performed at room temperature, yielding $\mathbf{2}^{22}(95 \%)$ and $\mathbf{3}^{23}(97 \%)$ as pale yellow oils.

SCS-pincer Ni complex 4 was prepared by oxidative addition of ligand 2 to $\left[\mathrm{Ni}(\mathrm{COD})_{2}\right]$ at $-80{ }^{\circ} \mathrm{C}$. The product is obtained as a diamagnetic yellow, air-stable solid in $72 \%$ yield. Addition of an excess of $\mathrm{CCl}_{4}$ to the complex (in $\mathrm{C}_{6} \mathrm{D}_{6}$ ) did not show any evidence of the formation of a nickel- $\mathrm{d}^{7}$ complex. This is in striking contrast to the high reactivity of $[\mathrm{NiCl}(\mathrm{NCN})]$ complexes, which oxidize readily with $\mathrm{CCl}_{4}$ to air- and waterstable nickel-d ${ }^{7}$ complexes $\left[\mathrm{NiCl}_{2}(\mathrm{NCN})\right]$. $\mathrm{CV}$ analysis of $\mathbf{4}$ showed an irreversible oxidation curve starting at $300 \mathrm{mV}$ (200 $\mathrm{mV} / \mathrm{s}, \mathrm{MeCN}, 8 \mathrm{mM}$ ). Presumably, an irreversible reaction occurs in which a Ni-d $\mathrm{d}^{7}$ complex is formed, which subsequently initiates a sulfur oxidation reaction or a reaction involving the aromatic backbone. Comparison of the ${ }^{1} \mathrm{H}$ NMR chemical shifts of 4 with those of the starting material 2 in $\mathrm{C}_{6} \mathrm{D}_{6}$ revealed a shift to lower frequency of the signal for the methylene groups of $4(\Delta \delta=-0.34 \mathrm{ppm})$, which appeared at $3.26 \mathrm{ppm}$ as a slightly broadened singlet. The methyl protons of $\mathbf{4}$ appear as a sharp peak at higher frequency as compared to 2 (2.14 ppm, $\Delta \delta=0.45 \mathrm{ppm})$.

(21) (a) Amijs, C. H. M.; van Klink, G. P. M.; van Koten, G. Green Chem. 2003, 5, 470-474. (b) Terheijden, J.; van Koten, G.; van Beek, J. A. M.; Vriesema, B. K.; Kellogg, R. M.; Zoutberg, M. C.; Stam, C. H. Organometallics 1987, 6, 89-93. (c) Vögtle, F. Chem. Ber. 1969, 102, 1784 1788.

(22) The compound was prepared using a modified synthetic procedure as reported by: (a) Evans, D. R.; Huang, M.; Seganish, W. M.; Chege, E. W.; Lam, Y.-F.; Fettinger, J. C.; Williams, T. L Inorg. Chem. 2002, 41, 2633-2641. (b) Bergholdt, A. B.; Kobayashi, K.; Horn, E.; Takahashi, O.; Sato, S.; Furukawa, N.; Yokoyama, M.; Yamagushi, K J. Am. Chem. Soc. 1998, 120, 1230-1236. Spectral data are in accordance with the published results.

(23) The compound is prepared using a modified procedure as reported by: Akiba, K.-Y.; Moriyama, Y.; Mizozoe, M.; Inohara, H.; Nishii, T.; Yamamoto, Y.; Minoura, M.; Hashizume, D.; Iwasaki, F.; Takagi, Y.; Ishimura, K.; Nagase, S. J. Am. Chem. Soc. 2005, 127, 5893-5901. Spectral data are in accordance with the published results.
Oxidative addition of $\mathbf{2}$ and $\mathbf{3}$ to $\left[\mathrm{Pd}_{2} \mathrm{dba}_{3}\right] \cdot \mathrm{CHCl}_{3}$ in benzene at room temperature afforded the corresponding SCS-pincer palladium complexes $\mathbf{5}$ and $\mathbf{7}$ as yellow solids in 71 and $69 \%$ yield, respectively. In the ${ }^{1} \mathrm{H}$ NMR spectrum of 7 , the chemical shift of the $\mathrm{CH}_{2}$ resonance appeared as a sharp singlet at 3.76 ppm, confirming the coordination of both S-donor atoms to the palladium center $(\Delta \delta=-0.28 \mathrm{ppm}$ as compared to the chemical shift of these resonances in 3). The corresponding ${ }^{\mathrm{Me}} \mathrm{SCS}$-pincer palladium complex 5 showed two broad overlapping signals at 3.48 and $3.27 \mathrm{ppm}$ for the benzylic protons (cf. the singlet at $3.60 \mathrm{ppm}$ in 2). These spectral features have also been observed for the benzylic protons in the ${ }^{1} \mathrm{H}$ NMR spectrum of the corresponding chloride complex $\left[\mathrm{PdCl}\left({ }^{\mathrm{Me}} \mathrm{SCS}\right)\right](9)$ reported by Pfeffer et al. (vide infra). ${ }^{13 b}$

The SCS-pincer Pt complexes $\mathbf{6}$ and $\mathbf{8}$ were prepared by reacting either $\mathbf{2}$ or $\mathbf{3}$ in benzene with the platination agent [Pt$(p \text {-tol })_{2}(\mu$-SEt 2$\left.)\right] .{ }^{20}$ The products were obtained as crystalline, light-yellow solids in $76 \%$ yield. In the ${ }^{1} \mathrm{H}$ NMR spectrum of 8 in $\mathrm{CDCl}_{3}$, the benzylic protons appeared as a broad doublet with the shape of an unresolved $\mathrm{AB}$ pattern $(\delta 4.89$ and 4.47 $\mathrm{ppm})$. The platinum satellites, also unresolved, appeared as small shoulders on each doublet. The ${ }^{1} \mathrm{H}$ NMR spectrum of $6\left(\mathrm{C}_{6} \mathrm{D}_{6}\right)$, however, showed two distinct patterns for the $\mathrm{CH}_{2}$ and $\mathrm{CH}_{3}$ resonances (Figure 2). The signals for the benzylic protons in this case appear as an $\mathrm{AX}\left(3.73,3.15 \mathrm{ppm},{ }^{2} J_{\mathrm{AX}}=15.7 \mathrm{~Hz}\right)$ and an $\mathrm{AB}$ pattern $\left(3.69,3.27 \mathrm{ppm},{ }^{2} J_{\mathrm{AB}}=15.7 \mathrm{~Hz}\right)$, both with platinum satellites. The presence of the two patterns is due to the stereogenity of each of the coordinated sulfur centers and, therefore, the complex exists in solution as two diastereoisomers, that is, rac (as RR and SS enantiomers) and meso (as RS and SR enantiomers) respectively, which are in slow exchange (vide infra). ${ }^{24}$ For $\mathbf{6}$ and $\mathbf{8}$, this is also reflected by the observation of two resonances in the ${ }^{195} \mathrm{Pt}$ NMR. For 6 singlets are found at -3967 and $-3980 \mathrm{ppm}$ and for $\mathbf{8}$ at -3967 and $-4001 \mathrm{ppm}^{25}$ Noteworthy are the different ${ }^{1} \mathrm{H}-{ }^{195} \mathrm{Pt}$ coupling constants for each of the diastereotopic benzylic protons of $\mathbf{6}$ (vide infra). Furthermore, two singlets at 2.25 and 2.18 ppm were observed for the S-methyl protons, accompanied by platinum satellites with a ${ }^{3} J_{\mathrm{PtH}}$ coupling of 52.8 and $53.4 \mathrm{~Hz}$, respectively.

Structures of 4-6, 8, and 9 in the Solid State. The structures of complexes $\mathbf{4}, \mathbf{5}, \mathbf{6}, \mathbf{8}$, and $\mathbf{9}$ in the solid state were studied by X-ray crystal structure determination. Single crystals of the complexes were obtained by slow evaporation of a concentrated solution in $\mathrm{CH}_{2} \mathrm{Cl}_{2}$. A selection of the crystal-

(24) (a) Evans, D. R.; Huang, M.; Seganish, M. W.; Fettinger, J. C.; Williams, T. L. Organometallics 2002, 21, 893-900. (b) Amijs, C. H. M.; van Klink, G. P. M.; Lutz, M.; Spek, A. L.; van Koten, G. Organometallics 2005, 24, 2944-2958.

(25) It must be noted that in ${ }^{195} \mathrm{Pt}$ NMR $(64.4 \mathrm{MHz})$ one can still observe processes that are roughly a factor 100 faster than exchange processes observed in the ${ }^{1} \mathrm{H}$ NMR $(300 \mathrm{MHz})$ spectrum. The meso related conformers exist as the pairs asymm $R_{\mathrm{ax}}, S_{\mathrm{eq}}-S_{\mathrm{eq}}, R_{\mathrm{ax}}$ and $R_{\mathrm{eq}}, S_{\mathrm{ax}}-S_{\mathrm{ax}}, R_{\mathrm{eq}}$ and as (true-) meso $R, S-S, R$ (see also later explanations in main text). These three pairs are likely responsible for the broadened signal at lower field in the ${ }^{195} \mathrm{Pt}$ NMR giving rise to the two observed shoulders. 


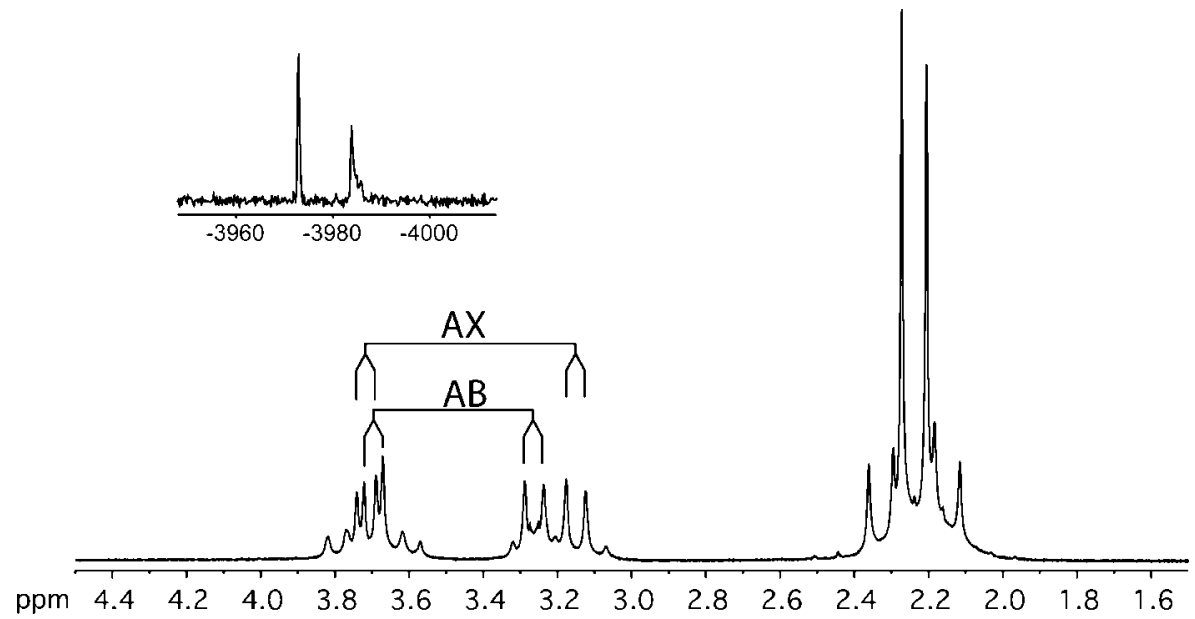

Figure 2. ${ }^{1} \mathrm{H}$ NMR spectrum of the aliphatic part of $\left[\mathrm{PtBr}\left({ }^{\mathrm{Me}} \mathrm{SCS}\right)\right] 6$ in $\mathrm{C}_{6} \mathrm{D}_{6}$ at room temperature of the diastereoisomers rac-6 and meso-6. Inset: ${ }^{195} \mathrm{Pt}$ NMR spectrum of $\mathbf{6}$.

Table 1. Selected Bond Distances and Angles and Torsion Angles of Structures 4-6, 8, and 9

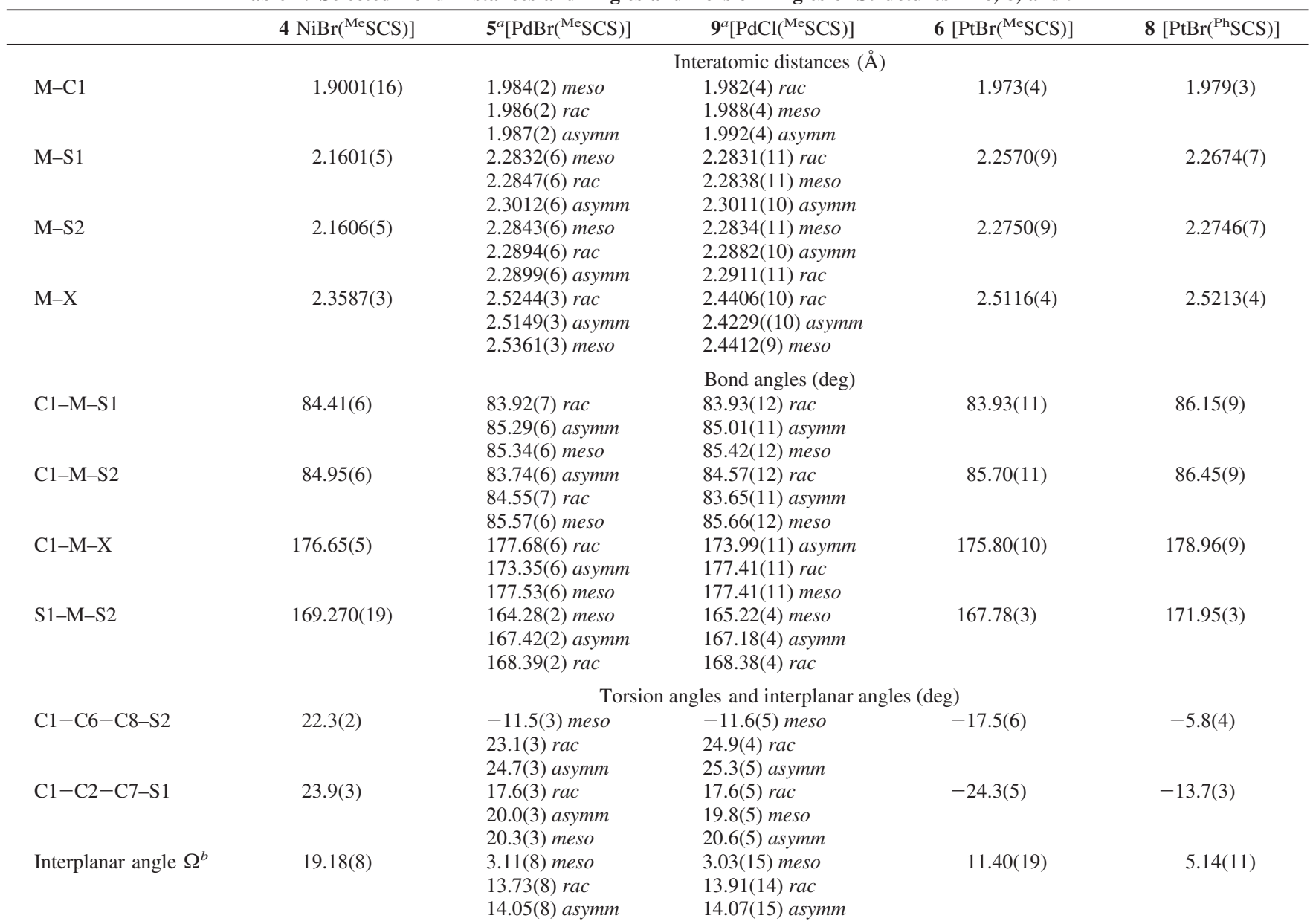

\footnotetext{
${ }^{a}$ Bond lengths are organized in ascending order. ${ }^{b}$ Interplanar angle $(\Omega)$ is defined as the angle between the least-squares plane of the anionic aryl
} ligand and the coordination plane.

lographic data obtained is listed in Table 1. Nickel complex 4 only exists in the rac-conformation and has approximate, noncrystallographic $C_{2}$ symmetry with the $C_{2}$-axis collinear to the $\mathrm{Br}-\mathrm{Ni} 1-\mathrm{C} 1$ bond (Figure 3 ). The methyl groups occupy equatorial positions and are orientated in opposite direction with respect to the square planar coordination plane ( $\mathrm{rac}$ conformation). As the crystal structure is centrosymmetric, the unit cell contains both enantiomers $\left(\mathrm{R}_{\mathrm{eq}}, \mathrm{R}_{\mathrm{eq}}\right.$ and $\left.\mathrm{S}_{\mathrm{eq}}, \mathrm{S}_{\mathrm{eq}}\right)$ of the racisomer, which form pairs in parallel alignment with opposite
$\mathrm{C}_{\mathrm{ipso}}-\mathrm{Ni}-\mathrm{Br}$ directions. ${ }^{26} \mathrm{~A}$ search in the Cambridge Crystallographic Database on organometallic nickel complexes bearing two trans-positioned thioether ligands revealed only a small number of structures. This was rather surprising given the fact that nickel sulfur complexes have received considerable attention in biomimetic studies related to their reactivity and role in biocatalytic pathways. ${ }^{27}$ The few reported organometallic Ni(II) thioether complexes comprised only tetrahedral structures. ${ }^{27 a}$ It is obvious that this geometry is less likely in rac-4 type 

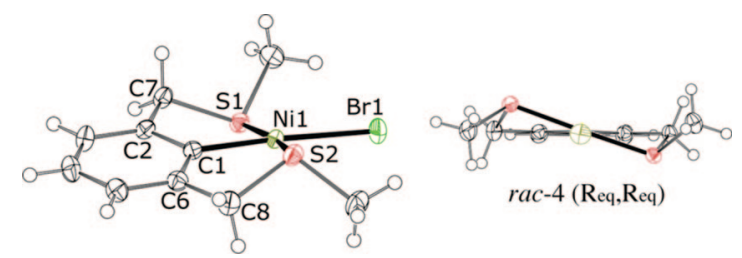

Figure 3. ORTEP representation of the molecular structure of one of the two enantiomers $\left(\mathrm{R}_{\mathrm{eq}}, \mathrm{R}_{\mathrm{eq}}, \mathrm{S}_{\mathrm{eq}}, \mathrm{S}_{\mathrm{eq}}\right.$ not shown) of rac-4. Displacement ellipsoids are drawn at the $50 \%$ probability level. (Inset) View along the axis through $\mathrm{Br}-\mathrm{Ni}-\mathrm{C} 1-\mathrm{C} 4$.

complexes as the pincer ligand with trans sulfur donor atoms imposes a square planar geometry around the metal- $\mathrm{d}^{8}$ nickel center, illustrating the special coordination mode of ECE-pincer ligands in organometallic chemistry. Similar NCN- and PCPpincer $\mathrm{Ni}(\mathrm{II})$ complexes have been prepared, and their crystal structures have been reported. The $\mathrm{Ni}-\mathrm{C} 1$ bond in the $\mathrm{NCN}$ complex $\left[\mathrm{NiBr}\left({ }^{\mathrm{Et}} \mathrm{NCN}\right)\right]^{28}$ is slightly shorter $(1.825 \AA)$ compared to $r a c-4$ (1.9001(16) $\AA$ ), whereas the same bond in the PCP complex $\left[\mathrm{NiBr}\left({ }^{\mathrm{Cy}} \mathrm{PCP}\right)\right]^{29}$ has nearly the same length $(1.908 \AA)$. Also the $\mathrm{C} 1-\mathrm{Ni}-\mathrm{E}(\mathrm{E}=$ donor atom) angles of rac-4 (84.41(6) and $\left.84.95(6)^{\circ}\right)$ are similar to those of the PCP complex (86.29 and $84.70^{\circ}$ ) and the NCN complex $\left(84.14\right.$ and $\left.84.45^{\circ}\right)$. Further evidence for deviation from an ideal square planar geometry is indicated by significant puckering of the two five membered metallacycles and the torsion angles $\mathrm{C} 1-\mathrm{C} 6-\mathrm{C} 8-\mathrm{S} 2\left(22.3(2)^{\circ}\right)$ and $\mathrm{C} 1-\mathrm{C} 2-\mathrm{C} 7-\mathrm{S} 1\left(23.9(2)^{\circ}\right)$. Consequently, a relatively large interplanar angle $\left(\Omega, 19.18(8)^{\circ}\right)$, defined as the angle between the calculated least-squares plane of the arene and the coordination plane, is found in $\mathrm{rac}-4$.

The crystal structure of $\left[\mathrm{PdBr}\left({ }^{\mathrm{Me}} \mathrm{SCS}\right)\right] \mathbf{5}$ contains three independent molecules in the asymmetric unit, which represent three different isomers of the complex (Figure 4). The first molecule, $r a c-5$, has approximate $C_{2}$-symmetry similar to $r a c$ 4. The second has one methyl group in axial and the other in equatorial position. Due to the presence of ring puckering in the two metallacycles, the molecule lacks any symmetry element and is therefore labeled as asymm-5. The third molecule is disordered. The major disorder component (95\%) has an approximate mirror plane though the $\mathrm{Br}-\mathrm{Pd}-\mathrm{C}$ bond and is the meso isomer, labeled meso-5 ( $C_{\mathrm{s}}$ symmetry). The minor component is a distorted $\mathbf{r a c}-\mathbf{5}$ structure $(5 \%)$.

During our first attempts to obtain suitable crystals for X-ray structure determination of $\mathbf{5}$ using chloroform as solvent, we found that the bromide atom was replaced by a chloride, giving chloride complex $9\left[\mathrm{PdCl}\left({ }^{\mathrm{Me}} \mathrm{SCS}\right)\right]$ instead. Traces of $\mathrm{HCl}$ in the solvent are most likely the cause of this halide exchange reaction during the recrystallization process. A similar observation has been made earlier by Bergbreiter et al. ${ }^{30}$ The crystals of $\mathbf{5}$ and $\mathbf{9}$ are nearly isomorphic, with the only difference that the $5 \%$ disorder observed for $\mathbf{5}$ is absent in the unit cell of $\mathbf{9}$. Hence, in the case of $\mathbf{9}$ the unit cell contains the rac-9, asymm-

(26) The abbreviations eq or ax indicate the orientation of the methyl group, equatorial or axial, respectively.

(27) (a) Schebler, P. J; Mandimutsira, B. S.; Riordan, C. G.; LiableSands, L. M.; Incarvito, C. D; Rheingold, A. L. J. Am. Chem. Soc. 2001, 123, 331-332. (b) Stavropoulos, P.; Muetterties, M. C.; Carrie, M.; Holm, R. H. J. Am. Chem. Soc. 1991, 113, 8485-8492.

(28) Schimmelpfennig, U.; Zimmering, R.; Schleinitz, K. D.; Stosser, R.; Wenschuh, E.; Baumeister, U.; Hartung, H. Z. Anorg. Allg. Chem. 1993, $619,1931-1938$.

(29) Kennedy, A. R.; Cross, R. J.; Muir, K. W. Inorg. Chim. Acta 1995, 231, 195-200.

(30) Bergbreiter, D. E.; Frels, J. D.; Rawson, J.; Li, J.; Reibenspies, J. H. Inorg. Chim. Acta 2006, 359, 1912-1922.
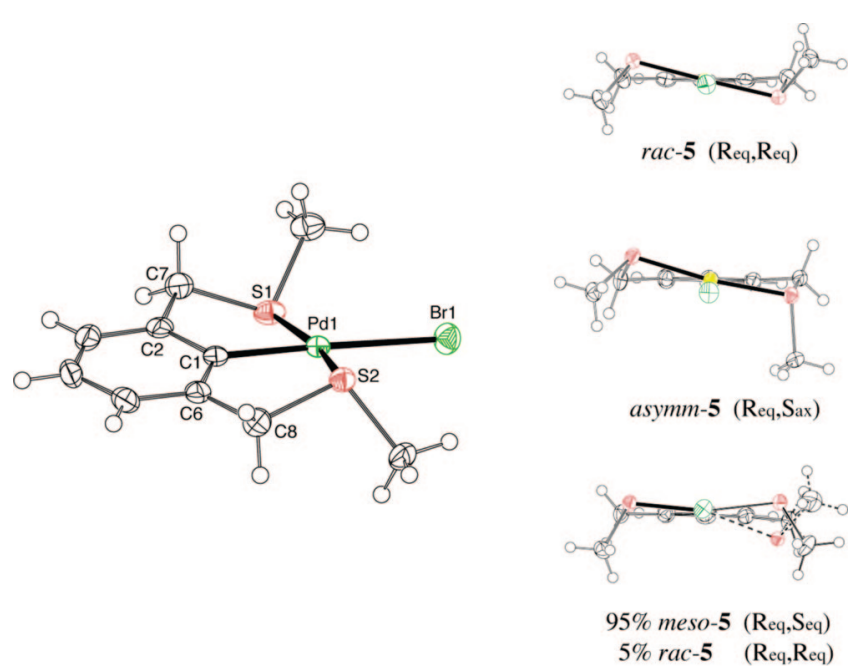

Figure 4. View of the molecular structure of rac-5. Displacement ellipsoids are drawn at the $50 \%$ probability level. Inset: View along the axis through $\mathrm{Br}-\mathrm{Pd}-\mathrm{C} 1-\mathrm{C} 4$ of the various isomers found in the crystal lattice.
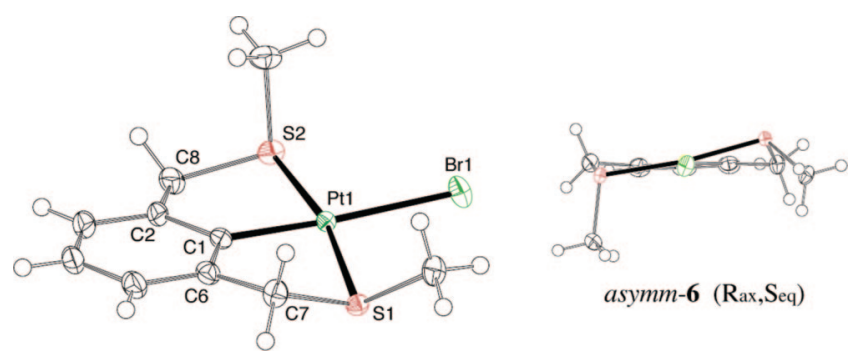

asymm-6 (Rax,Seq)

Figure 5. ORTEP representation of the molecular structure of asymm-6. Displacement ellipsoids are drawn at the 50\% probability level. (Inset) View along the axis through $\mathrm{Br}-\mathrm{Pt}-\mathrm{C} 1-\mathrm{C} 4$.

9, and meso-9 isomers. Bond lengths and angles differ only marginally in the corresponding isomers of $\mathbf{5}$ and $\mathbf{9}$, indicating that the halide ligand has only a small effect on their structural features (Table 1). The $\mathrm{Pd}-\mathrm{C}$ bond lengths for the different conformations of 5 are between 1.984(2) and 1.987(2) $\AA$ and between 1.982(4) and 1.992(4) $\AA$ for 9, which is within the range of reported SCS-pincer palladium complexes (1.964-1.994 $\AA) .{ }^{13}$ Also the distortions from an ideal square planar geometry, dictated by the $\mathrm{S} 1-\mathrm{Pd}-\mathrm{S} 2$ bond angles $\left(164.28(2)-168.39(2)^{\circ}\right.$, in 5) and the $\mathrm{C} 1-\mathrm{Pd}-\mathrm{S}$ angles $\left(83.65-85.57^{\circ}\right.$, in 5) do not deviate from reported $[\mathrm{Pd}($ halide $)(\mathrm{SCS})]$ structures.

The SCS-pincer Pt complex 6 [PtBr( $\left.\left.{ }^{\mathrm{Me}} \mathrm{SCS}\right)\right]$ crystallized in a single conformational structure with one axial and one equatorial orientated S-methyl group (asymm-6, Figure 5). The molecule has a similar structure as the corresponding Pdcomplex asymm-5. Bond lengths involving the platinum atom are shorter compared to asymm-5, which is due to the smaller ionic radius of $\mathrm{Pt}(\mathrm{II})$ and a stronger binding of the donor atoms to the metal center. ${ }^{31}$ The $\mathrm{C}_{\mathrm{ipso}}-\mathrm{Pt}$ bond in asymm-6 has a length of 1.973(4) $\AA$, which is shorter than those found in the two reported SCS-pincer Pt complexes (1.982 and 2.040 ^). ${ }^{17}$ The $\mathrm{C}-\mathrm{Pt}-\mathrm{S}$ angles are $83.93(11)$ and $85.70(11)^{\circ}$ and the interplanar angle $\Omega$ is $11.40(19)^{\circ}$, being slightly smaller as compared to asymm-5.

The platinum complex $\left[\mathrm{PtBr}\left({ }^{\mathrm{Ph}} \mathrm{SCS}\right)\right] \mathrm{rac}-\mathbf{8}$ has both thiophenyl substituents in axial position with respect to the coordination

(31) Ionic radii of $\mathrm{Ni}(\mathrm{II}), \mathrm{Pd}(\mathrm{II})$, and $\mathrm{Pt}(\mathrm{II})$ atoms in a square planar geometry are $0.49,0.64$, and $0.60 \AA$ respectively. Handbook of Chemistry and Physics, 85th ed.; 2004, 12-14. 


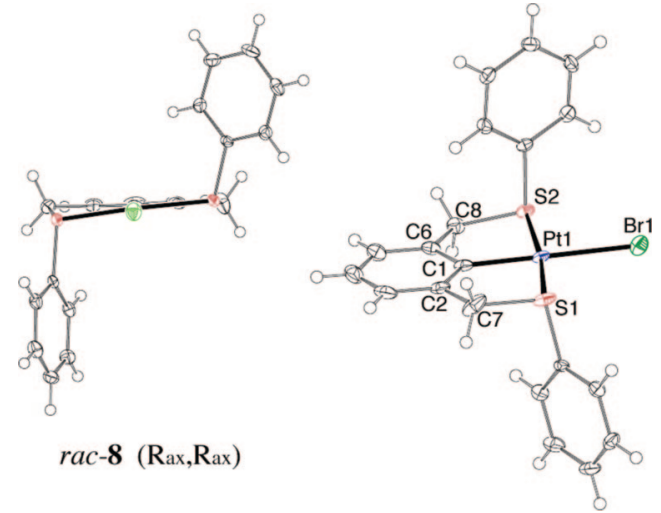

Figure 6. ORTEP representation of the molecular structure of rac8. Displacement ellipsoids are drawn at the $50 \%$ probability level. Left: View along the axis through $\mathrm{Br}-\mathrm{Pt}-\mathrm{C} 1-\mathrm{C} 4$.

plane (Figure 6). Both the $\mathrm{Pt}-\mathrm{C}(1.979(3) \AA)$ and the $\mathrm{Pt}-\mathrm{S} 1$ $(2.2674(7) \AA)$ bond lengths are slightly longer compared to those in asymm-6 (Table 1). The $\mathrm{C}-\mathrm{Pt}-\mathrm{S}$ angles (86.16(9) and $\left.86.44(9)^{\circ}\right)$ are larger as those in asymm-6, whereas the $\mathrm{C} 1-\mathrm{C} 6-\mathrm{C} 8-\mathrm{S} 2$ and $\mathrm{C} 1-\mathrm{C} 2-\mathrm{C} 7-\mathrm{S} 1$ torsion angles $(5.8(4)$ and $13.7(3)^{\circ}$, respectively) are smaller as in asymm-6, suggesting that a lower ring strain is present in the metallacycles of $\mathrm{rac}-\mathbf{8}$ compared to asymm-6.

The observed rac isomers with methyl groups in equatorial positions for 4-6 and 9 are most probably a result of the small size of the methyl substituent. Larger substituents are likely directed into the axial position (see 8, Figure 6) to obtain an optimal spatial arrangement and morphology during crystallization. Apparently, ${ }^{\mathrm{Me}} \mathrm{SCS}$-pincer complexes show different structural behavior because the thiomethyl substituents require less space and therefore can adopt various orientations in the solid-state, as found in the crystal structures of complexes 4-6 and 9.

Structures in Solution. The fluxional behavior of SCS-metal complexes in solution, as studied by NMR spectroscopy, is rather complicated. ${ }^{13 \mathrm{~b}}$ However, with the structural data of complexes 4-6 and $\mathbf{8}$ found in the solid-state now in hand, we can try to visualize possible exchange processes for these complexes in solution (Scheme 3). Two concurrent processes can be envisaged: (1) inversion of the sulfur configuration (s.i.) and (2) concomitant ring puckering inversion (r.i.) of the two metallacycles, which have been suggested by Pfeffer et al. in their preliminary study of the exchange behavior of complex 9 in solution. ${ }^{13 b}$ As illustrated in Scheme 3, different isomers, which can exist in a number of conformations, are considered to be involved in this mechanism. Scheme 3 considers two rac isomers: a $r a c_{\mathrm{eq}}$ complex with equatorial methyl groups and a $r a c_{\mathrm{ax}}$ complex with the methyl in axial position. These two $\mathrm{rac}$ conformations are interconvertable by ring puckering inversion. The three other structures presented in Scheme 3 are one meso and two asymm isomers, of which the latter two are enantiomers. The meso structure can be regarded as the time-average conformer of both asymm conformations of which the latter have substantially more ring puckering. In the ${ }^{1} \mathrm{H}$ NMR spectrum of ${ }^{\mathrm{Me}} \mathrm{SCSPtBr} 6$, two molecules are observed (Figure 2), which means that one of the above-mentioned processes is in the slow exchange limit range at room temperature (vide supra). For the actual exchange process in solution, four possibilities can now be envisaged: (1) both processes (r.i. and s.i.) are fast, (2) both processes are slow, (3) only sulfur inversion is fast, or (4) only ring inversion is fast on the NMR time scale. In the fast exchange limit, both processes occur fast on the NMR time
Scheme 3. Dynamic Processes between rac and meso Isomers of the MX-SCS Complexes ${ }^{a}$

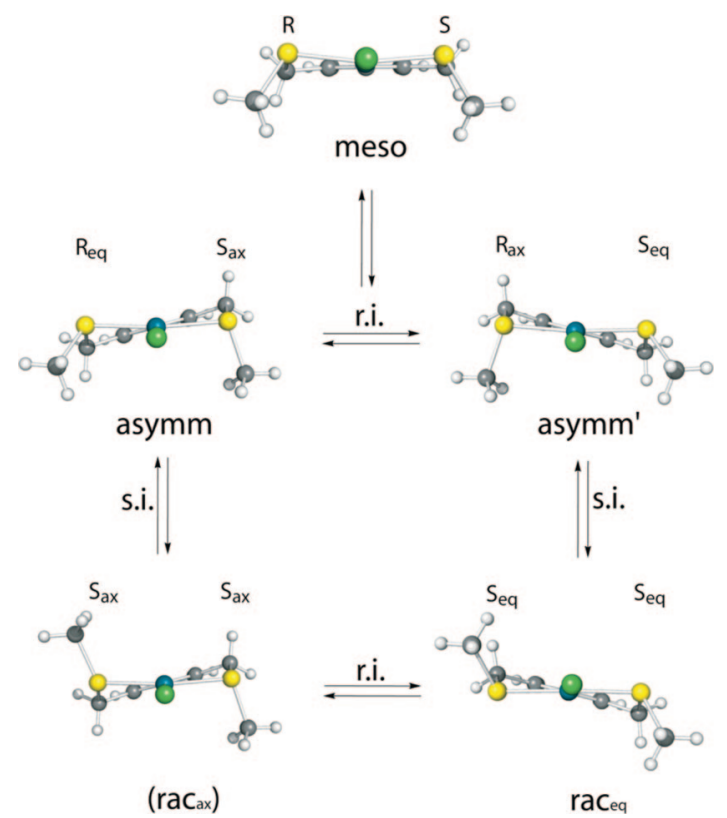

${ }^{a}$ The dynamic processes in solution involving a single-site sulphur inversion (s.i.) and ring puckering inversion (r.i.). Some of the structures found in the unit cell of the crystal structure of $\mathbf{9}$ are used for this picture (i.e. $m e s o-9, \operatorname{rac}_{\mathrm{eq}} \mathbf{- 9}$, asymm-9; structure $\operatorname{rac}_{\mathrm{ax}} \mathbf{- 9}$ is not present in the crystal structure of $\mathbf{9}$ therefore a molecular model (SPARTAN Software package) of this conformer was used to illustrate the possible structures).

scale: that is, one benzylic resonance should be observed for all the complexes. This is not the case. If the ring puckering and sulfur inversion would both be in the slow exchange limit, one would expect to see more than two $A B$ patterns (or $A B$ and $\mathrm{AX}$ ), at least one for each unique conformation. In that case, conformer $r a c_{\mathrm{eq}}, r a c_{\mathrm{ax}}$, and meso will all give one $\mathrm{AB}$ or $\mathrm{AX}$ pattern and asymm an $\mathrm{AB}$ and $\mathrm{AX}$ pattern, since it lacks any symmetry. In total, at least 5 pairs of doublets for the benzylic protons would be expected in the ${ }^{1} \mathrm{H}$ NMR spectrum, which is clearly not the case. If only ring puckering is in the slow exchange limit and sulfur inversion would be fast, no meso or rac conformer would be observed in solution due to the fast exchange of the methyl groups in the structures. The time average structure would only have two different conformers having opposite ring puckering orientations. These structures are enantiomers and would thus result in only one AB pattern in the slow exchange limit in the ${ }^{1} \mathrm{H}$ NMR spectrum. Therefore, the only option left is that sulfur inversion is in the slow exchange limit and ring puckering is fast on NMR time scale. Since ring puckering (r.i.) is fast in this case, the puckering time-average isomers have a structure related to the meso (since the asymm-conformers are in fast exchange) and $r a c$ ( $r a c_{\mathrm{eq}}$ and rac $_{\mathrm{ax}}$, Scheme 3) conformers and will together give two AB (or $\mathrm{AB}$ and $\mathrm{AX}$ ) patterns in the ${ }^{1} \mathrm{H}$ NMR spectrum, as observed for 6 . We have to note here that the assumption was made that sulfur inversion occurs without decoordination of the sulfur atom, which is the generally accepted mechanism for thioether platinum complexes. ${ }^{32}$ In addition, no evidence was found for uncoordinated sulfur atoms in the ${ }^{1} \mathrm{H}$ NMR spectra at low temperature (vide infra).

The ${ }^{1} \mathrm{H}$ NMR spectra of 4 ([NiBr( $\left.\left.\left.{ }^{\mathrm{Me}} \mathrm{SCS}\right)\right]\right)$ and $\mathbf{5}$ ([PdBr$\left.\left.\left({ }^{\mathrm{Me} S C S}\right)\right]\right)$ at low temperatures $\left(<240 \mathrm{~K}\right.$, toluene- $\left.d_{8}\right)$ showed

(32) Oki, M. Pure Appl. Chem. 1989, 61, 699-708. 

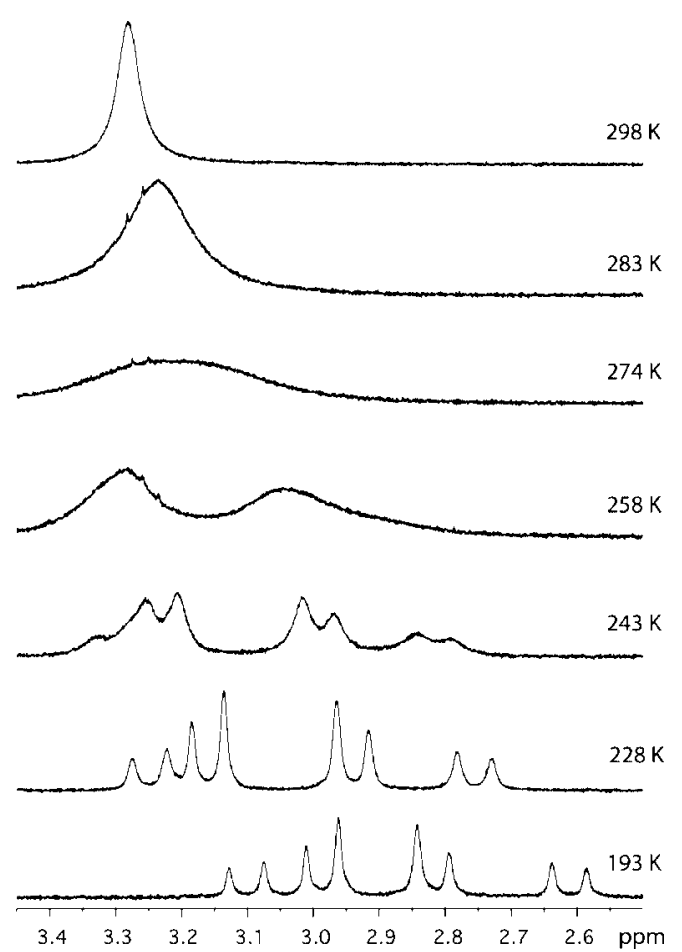

Figure 7. ${ }^{1} \mathrm{H}$ NMR (toluene- $d_{8}$ ) of the benzylic protons of $\left[\mathrm{NiBr}\left({ }^{\mathrm{Me}} \mathrm{SCS}\right)\right] \mathbf{4}$ at various temperatures showing the coalescence of the AB and AX patterns of RR/SS (rac-4) and SS/SR (meso-4).

features that are consistent with the presence of two complexes in solution, similar to 6 at room temperature. Clearly, separated $\mathrm{AB}$ and $\mathrm{AX}$ patterns were observed for the diastereotopic benzylic protons of both $\mathbf{4}$ and 5 (Figure 7 shows typical example for 4). The same phenomenon has also been observed in the spectrum of 9 at $233 \mathrm{~K}^{13 \mathrm{~b}}$ It appears that at the slow exchange limit one of the isomers or conformers is preferred. For both $\mathbf{4}$ and $\mathbf{5}$, the two isomers are observed in a 6:4 molar ratio with the isomer giving rise to the $A B$ pattern being the more abundant.

At $223 \mathrm{~K}$ the benzylic resonances showed a broad singlet for Pd-complex 7 ([PdBr $\left.\left.\left({ }^{\mathrm{Ph}} \mathrm{SCS}\right)\right]\right)$, indicating similar behavior as observed for 4-6. Unfortunately, the coalescence temperature for the $\mathrm{CH}_{2}$ resonances could not be observed for 7 due to insolubility of the complex in toluene- $d_{8}$ below $223 \mathrm{~K}$. The spectrum of Pt-complex $\mathbf{8}$ displayed an unresolved AB pattern at $273 \mathrm{~K}$, this in contrast to the Pt-complex 6, which showed two distinct patterns at room temperature. In this case. the slow exchange limit could be observed since the complex was still slightly soluble at $248 \mathrm{~K}$. Full separation of the AB and AX signals was observed, although the platinum satellites were not visible in the ${ }^{1} \mathrm{H}$ NMR spectrum.

At room temperature, the ${ }^{1} \mathrm{H}$ NMR spectra of $\mathbf{4}, \mathbf{5}$, and $\mathbf{6}$ bearing the ${ }^{\mathrm{Me}} \mathrm{SCS}$ ligand displayed three different exchange stages (Figure 8). The $\mathrm{CH}_{2}$ resonances for the Ni-complex 4 are in the fast exchange limit (singlet), the same resonances for the $\mathrm{Pd}$ complex $\mathbf{5}$ are in the intermediate exchange (broad doublet) and the corresponding resonances for the Pt complex 6 are in the slow exchange limit ( $\mathrm{AB}$ and $\mathrm{AX}$ patterns). The same trend is also observed for the thiophenyl complexes 7 and 8. This trend was also reflected in the coalescence temperatures of the benzylic proton signals, which are listed in Table 2 (toluene- $d_{8}$ ). Comparing the $T_{\mathrm{c}}$ values for $\mathbf{4 , 5}$, and $\mathbf{6}$, an increase in coalescence temperature for the benzylic protons in the series was observed. This dependence of the coalescence temperature
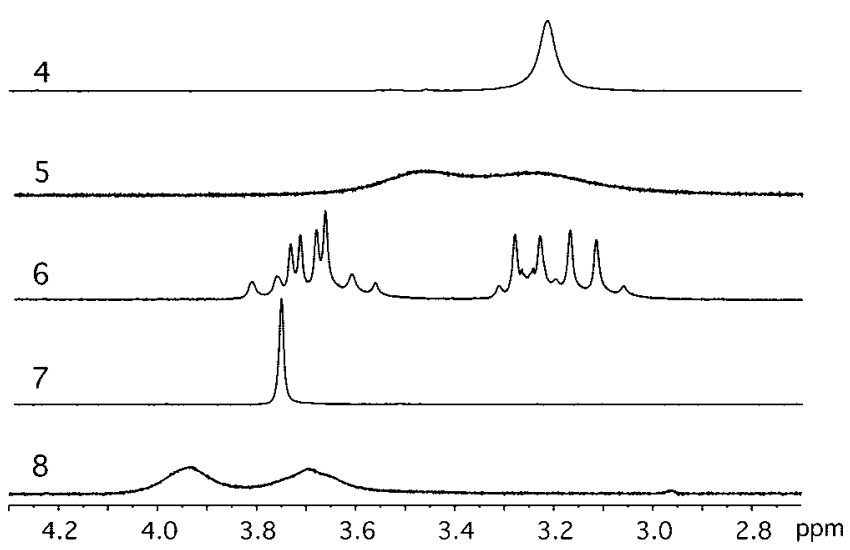

Figure 8. Part of the ${ }^{1} \mathrm{H}$ NMR spectra showing the two patterns of $\mathrm{CH}_{2}$ resonances of complexes $\mathbf{4}-\mathbf{8}$ at room temperature $\left(\mathrm{C}_{6} \mathrm{D}_{6}\right)$.

Table 2. Coalescence Temperature of the Benzylic Protons (Toluene- $d_{8}$ )

\begin{tabular}{cl}
\hline complex & $T_{\mathrm{c}}(\mathrm{K})$ \\
\hline $\mathbf{4}$ & 274 \\
$\mathbf{5}$ & 305 \\
$\mathbf{6}$ & 370 \\
$\mathbf{7}$ & $<223$ \\
$\mathbf{8}$ & 308
\end{tabular}

of exchanging resonances in platinum and palladium complexes bearing chelating thioether ligands has been reported before for other complexes. The relative exchange rate is believed to depend on the metal mass and size and reflects the relative strength of the $\mathrm{M}-\mathrm{S}$ bond, which is the strongest for the platinum complexes. ${ }^{33}$ Thus, even though $\mathrm{M}-\mathrm{S}$ bond breaking does not occur during these exchange processes (vide supra), the strength of the $\mathrm{M}-\mathrm{S}$ bond definitely plays an important role in the fluxional behavior occurring at the metal center. Whereas SCS-pincer palladium complexes bearing phenyl, ${ }^{13 \mathrm{c}} t$-butyl, ${ }^{13 \mathrm{a}}$ $i$-propyl, ${ }^{13 \mathrm{n}}$ or ethyl ${ }^{13 \mathrm{c}}$ groups on the sulfur donor atoms show in the ${ }^{1} \mathrm{H}$ NMR spectrum $\left(\mathrm{CDCl}_{3}\right)$ a (in some cases broadened) singlet for the benzylic protons, the spectrum of $\mathbf{5}$ showed two broad, overlapping signals (3.6-3.0 ppm) at 3.48 and $3.27 \mathrm{ppm}$ in the same solvent. ${ }^{13 \mathrm{~b}}$ In general, compounds with larger substituents on the sulfur donor atoms give lower coalescence temperatures of the benzylic- $\mathrm{CH}_{2}$ resonances (also compare $\mathbf{5}$ and 7). ${ }^{33}$

Assignment of the AB and AX Patterns. On the basis of the given structural data in solution and in the solid-state, an accurate estimate can now be made to assign the $\mathrm{AX}$ or $\mathrm{AB}$ patterns in the ${ }^{1} \mathrm{H}$ NMR of 6 to a rac or meso structure. Since we have obtained the rac and meso isomers of complex 9 only in the solid state, we can compare the dihedral angles $\left(\mathrm{Pd}-\mathrm{S}-\mathrm{C}_{7 /}\right.$ $\left.{ }_{8}-\mathrm{H}_{\mathrm{A} / \mathrm{B}}\right)$ of rac-9 and meso-9 and translate this data to the platinum analogue 6. Hereby, we assume that the metal center has little influence on the observed dihedral angles, which is confirmed upon comparison of the various dihedral angles of the X-ray structures of ${ }^{\mathrm{Me}} \mathrm{SCSPtBr}$ asymm-6 (only crystallized conformation of 6) and ${ }^{\mathrm{Me}} \mathrm{SCSPdCl}$ asymm-9; only minor differences were observed and they show the same absolute trend. We observed that the difference between the appropriate dihedral angles of the geminal protons $\mathrm{H}_{\mathrm{A}}$ and $\mathrm{H}_{\mathrm{B}}$ of $\mathbf{9}$ is smaller for the meso isomer than for the rac isomer $(\Delta=41$ (meso) vs 49 ( rac) for $\mathrm{H}_{7}$ and $\Delta=21$ (meso) vs 57 ( rac) for $\mathrm{H}_{8}$, Table 3). The ${ }^{1} \mathrm{H}$ NMR spectrum of the SCS-pincer platinum complex

(33) Orrel, K. G.; Sik, V.; Brubaker, C. H.; McCulloch, B. J. Organomet. Chem. 1984, 267, 267. 
Table 3. Absolute Dihedral Angles of Two Isomers of 9
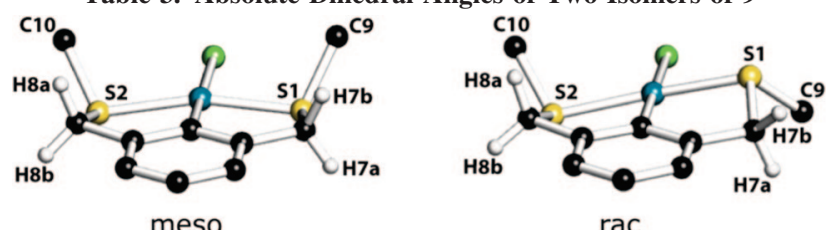

rac

\begin{tabular}{lccrc}
\hline dihedral angles & meso-9 & $\Delta$ & rac-9 & $\Delta$ \\
\hline C9-S1-C7-H7a & 11 & 97 & 16 & 19 \\
C9-S1-C7-H7b & 108 & & 103 & \\
C10-S2-C8-H8a & 116 & 113 & 19 & 81 \\
C10-S2-C8-H8b & 3 & & 100 & \\
Pd-S1-C7-H7a & 100 & 41 & 96 & 49 \\
Pd-S1-C7-H7b & 141 & & 145 & \\
Pd-S2-C8-H8a & 110 & 21 & 92 & 57 \\
Pd-S2-C8-H8b & 131 & & 149 &
\end{tabular}

6 has different accompanying platinum satellite coupling constants $\left(J_{\mathrm{HPt}}\right)$ for the observed four doublets of the benzylic resonances as well as for both methyl signals in the slow exchange limit (room temperature). Similar to the Karplus relation for $J_{\mathrm{HH}}$ coupling constants of vicinal protons, a relation between dihedral angles and $J_{\mathrm{HPt}}$ coupling constants is known. ${ }^{34}$ It was reported that the $J_{\mathrm{HPt}}$ increases with increasing dihedral angle, with a maximum at an angle of $180^{\circ}$ and a minimum at $0^{\circ}$. From this theory, it follows that the structure with the largest difference in dihedral angles, that is, between $\mathrm{Pd}-\mathrm{S}-\mathrm{C}_{7}-\mathrm{H}_{7} \mathrm{a}$ and $\mathrm{Pd}-\mathrm{S}-\mathrm{C}_{7}-\mathrm{H}_{7 \mathrm{~b}}$ and between $\mathrm{Pd}-\mathrm{S}-\mathrm{C}_{8}-\mathrm{H}_{8 \mathrm{a}}$ and $\mathrm{Pd}-\mathrm{S}-\mathrm{C}_{8}-\mathrm{H}_{8 \mathrm{~b}}$, will also exhibit the largest difference in $J_{\mathrm{HPt}}$ coupling constants for $\mathbf{6}$, that is, between $J_{\mathrm{HPt}}\left(\mathrm{H}_{\mathrm{A}}\right)$ and $J_{\mathrm{HPt}}\left(\mathrm{H}_{\mathrm{B}}\right)$ in both isomers (meso and $r a c$ ). When we measured the $J_{\mathrm{HPt}}$ coupling constants (room temperature, slow exchange limit) of the platinum complex $\mathbf{6}$, we observed that for the $\mathrm{AX}$ pattern the difference between $J_{\mathrm{HPt}}\left(\mathrm{H}_{\mathrm{A}}\right)$ and $J_{\mathrm{HPt}}\left(\mathrm{H}_{\mathrm{B}}\right)$ of the corresponding doublets is smaller than that of the $\mathrm{AB}$ pattern $(\Delta 8.9 \mathrm{vs}$ $\Delta 12.0 \mathrm{~Hz}$ ). This would mean that the AX pattern corresponds to the isomer with the smallest dihedral angle difference. Hence, from this analysis, it was concluded that the meso configuration gives rise to the $\mathrm{AX}$ pattern in the NMR spectrum and the $r a c$ configuration to the $\mathrm{AB}$ pattern.

\section{Conclusion}

The present study shows that oxidative addition metalation procedures provide facile access to SCS-pincer metal complexes $(\mathrm{M}=\mathrm{Ni}, \mathrm{Pd}, \mathrm{Pt})$. Various crystal structures of SCS complexes containing $\mathrm{Ni}, \mathrm{Pd}$, and $\mathrm{Pt}$ are described and each of these structures shows a unit cell with a unique set of independent $\left[\mathrm{MBr}\left({ }^{\mathrm{R}} \mathrm{SCS}\right)\right]$ molecules. Crystal structures of the Pd complexes 5 and 9 even showed the presence of three independent molecules in a single unit cell with rac, meso, and asymmetric conformations. NMR studies revealed that in solution pyramidal sulfur inversion is a much slower process than the ring puckering inversion for these types of complexes. By relating the solid state structures of $\left[\mathrm{PdCl}\left({ }^{\mathrm{Me}} \mathrm{SCS}\right)\right] \mathbf{9}$ to the fluxional behavior of $\left[\mathrm{PtBr}\left({ }^{\mathrm{Me}} \mathrm{SCS}\right)\right] \mathbf{6}$ in solution, assignment of the meso- and $r a c$-isomers in solution was possible.

Understanding the dynamic processes that take place at the metal site of these SCS pincer metal complexes in solution is

(34) Similar to the Karplus relationship for $J_{\mathrm{H}, \mathrm{H}}$ coupling constants of vicinal protons, a Karplus-like relationship between dihedral angles and $J_{\mathrm{H}, \mathrm{Pt}}$ has been reported. However, whereas the traditional Karplus relationship has a minimum $J_{\mathrm{H}, \mathrm{H}}$ at an angle of $90^{\circ}$, the $J_{\mathrm{Pt}, \mathrm{H}}$ has a minimum at an angle of $0^{\circ}$. See also: (a) Erickson, L. E.; McDonald, J. W.; Howie, J K.; Clow, R. P. J. Am. Chem. Soc. 1968, 90, 6371-6382. (b) Sarneski, J. E.; Erickson, L. E.; Reilley, C. N. Inorg. Chem. 1981, 20, 2137-2146. important since it will influence the outcome of e.g. a catalytic reaction. For the SCS-pincer Pt complexes, ${ }^{195} \mathrm{Pt}$ NMR of SCSpincer Pt complexes can show directly the relative abundance of conformational structures in solution, that is, rac versus meso. It is very interesting to investigate whether it is possible to influence the rac:meso ratio with an external stimulus since this might create chiral pockets (S-atoms are chiral) around the metal center and is thus a way to influence (selective) processes occurring at the metal center. We are currently studying this in conjunction with the application of SCS-pincer Pd-complexes as catalysts embedded in a lipase as it is known that the protein modification process (see Scheme 1) is sensitive toward small changes in the pincer ligand moiety. ${ }^{11}$

\section{Experimental Section}

General. All reactions were performed under a dry nitrogen atmosphere by standard Schlenk techniques. Solvents were carefully dried and distilled from sodium benzophenone (pentane, hexane, toluene, $\mathrm{C}_{6} \mathrm{H}_{6}$, THF, $\left.\mathrm{Et}_{2} \mathrm{O}\right)$ or $\mathrm{CaH}\left(\mathrm{CH}_{2} \mathrm{Cl}_{2}\right)$ prior to use. The compounds 1, ${ }^{21 \mathrm{a}}\left[\left\{\mathrm{Pt}(p \text {-tol })_{2}\left(\mu-\mathrm{SEt}_{2}\right)\right\}_{2}\right]^{35}$ and $\left[\mathrm{Pd}_{2} \mathrm{dba}_{3}\right] \cdot \mathrm{CHCl}_{3}{ }^{36}$ were synthesized according to literature procedures. All other chemicals were obtained commercially and were used without further purification. NMR spectra were recorded at $298 \mathrm{~K}$ on a Varian Inova 300 spectrometer and the chemical shifts were referenced to residual solvent resonances (ppm). ${ }^{195} \mathrm{Pt}\left\{{ }^{1} \mathrm{H}\right\}$ NMR $(64.4 \mathrm{MHz})$ spectra referenced using an external reference (1 M $\mathrm{K}_{2} \mathrm{PtCl}_{6}$ in $\left.\mathrm{D}_{2} \mathrm{O}, \delta=0 \mathrm{ppm}\right)$. Elemental analyses were performed by Dornis and Kolbe, Mikroanalytisches Laboratorium (Müllheim a/d Ruhr, Germany).

[ $\left.\mathbf{C}_{6} \mathbf{H}_{2}\left(\mathbf{C H}_{2} \mathbf{S M e}\right)_{2}-\mathbf{2 , 6}-\mathbf{B r}-1\right]$ (2). Solid $\mathbf{1}$ (1.0 g, $\left.2.92 \mathrm{mmol}\right)$ was dissolved in THF (100 mL) and NaSMe (0.97 g, $13.8 \mathrm{mmol})$ was added in one portion. The reaction mixture was stirred for $16 \mathrm{~h}$ at room temperature. Diethyl ether $(100 \mathrm{~mL})$ and an aqueous solution of $\mathrm{NaOH}(1 \mathrm{M}, 100 \mathrm{~mL})$ were added and the mixture stirred for $30 \mathrm{~min}$. The organic phase was separated and the aqueous phase extracted with diethyl ether $(2 \times 150 \mathrm{~mL})$. The organic fractions were combined, dried on $\mathrm{MgSO}_{4}$, and concentrated to colorless oil, which solidified upon standing to a white solid. Yield $0.78 \mathrm{~g} \mathrm{(97 \% ).}$ ${ }^{1} \mathrm{H}$ NMR (200 MHz, $\left.\mathrm{CDCl}_{3}\right): \delta 7.23$ (bs, ArH, 3H), $3.85\left(\mathrm{~s}, \mathrm{CH}_{2} \mathrm{~S}\right.$, $4 \mathrm{H}), 2.06(\mathrm{~s}, \mathrm{SMe}, 6 \mathrm{H}) .{ }^{13} \mathrm{C} \mathrm{NMR}\left(\mathrm{CDCl}_{3}\right): \delta 138.86,129.62$, 127.62, 127.00 (s, ArC), 39.62 (s, $\mathrm{CH}_{2}$ ), 15.58 (s, SMe). Anal. Calcd for $\mathrm{C}_{10} \mathrm{H}_{13} \mathrm{BrS}_{2}$ : C, 43.32; $\mathrm{H}, 4.73 ; \mathrm{S}, 23.13$. Found: $\mathrm{C}, 43.28 ; \mathrm{H}$, 4.76; S, 23.05.

[ $\mathbf{C}_{6} \mathbf{H}_{2}\left(\mathrm{CH}_{2} \mathbf{S P h}\right)_{\mathbf{2}}$-2,6-Br-1] (3). Thiophenol (3.02 g, $2.82 \mathrm{~mL}$, $27.4 \mathrm{mmol}), \mathrm{K}_{2} \mathrm{CO}_{3}(5.68 \mathrm{~g}, 41.1 \mathrm{mmol}), 1$ (2.35 g, $\left.6.85 \mathrm{mmol}\right)$ and 18-crown-6 (5 mg, $15.3 \mathrm{mmol})$ were dissolved in diethyl ether $(100 \mathrm{~mL})$ and stirred for $16 \mathrm{~h}$ at room temperature. A solution of $\mathrm{NaOH}(4 \mathrm{M}, 100 \mathrm{~mL}$ ) was added and the mixture stirred for 30 min. The organic phase was separated and the aqueous phase extracted with diethyl ether $(2 \times 100 \mathrm{~mL})$. The organic fractions were combined, dried on $\mathrm{MgSO}_{4}$ and concentrated to a yellowish oil. Yield $2.61 \mathrm{~g}(95 \%)$. ${ }^{1} \mathrm{H}$ NMR $\left(300 \mathrm{MHz}, \mathrm{CDCl}_{3}\right)$ : $\delta 7.36-7.04$ (bm, ArH, 13H), 4.29 (s, $\left.\mathrm{CH}_{2}\right) .{ }^{13} \mathrm{C} \mathrm{NMR}\left(75 \mathrm{MHz}, \mathrm{CDCl}_{3}\right): \delta$ 138.05, 136.00, 131.01, 129.88, 129.16, 127.15, 127.03, 126.96 (s, ArC), $40.84\left(\mathrm{~s}, \mathrm{CH}_{2} \mathrm{~S}\right)$. Anal. Calcd for $\mathrm{C}_{20} \mathrm{H}_{17} \mathrm{BrS}_{2}$ : C, 59.85; $\mathrm{H}$, 4.27; S, 15.98. Found: C, 60.08; H, 4.36; S, 15.86 .

$\left[\mathrm{NiBr}\left(\mathrm{C}_{6} \mathrm{H}_{2}\left(\mathrm{CH}_{2} \mathrm{SMe}\right)_{2}-\mathbf{2 , 6}\right)\right]$ (4). The complex was prepared according a modified literature procedure. ${ }^{18}$ A yellow solution of [Ni(COD $\left.)_{2}\right](0.34 \mathrm{~g}, 1.23 \mathrm{mmol})$ in THF $(150 \mathrm{~mL})$ was cooled to $-78{ }^{\circ} \mathrm{C}$ and a solution of $2(0.34 \mathrm{~g}, 1.23 \mathrm{mmol})$ in THF $(50 \mathrm{~mL})$ was added dropwise. The reaction mixture was stirred for $30 \mathrm{~min}$ at $-80{ }^{\circ} \mathrm{C}$ and subsequently allowed to warm to room temperature

(35) Steele, B. R.; Vrieze, K. Transition Met. Chem. 1977, 2, 140-144.

(36) Komiya, S. Synthesis of Organometallic Compounds; Wiley: Chichester, U.K., 1997. 
Table 4. Experimental Details for the X-Ray Crystal Structure Determinations

\begin{tabular}{|c|c|c|c|c|c|}
\hline & 4 & 5 & 6 & 8 & 9 \\
\hline formula & $\mathrm{C}_{10} \mathrm{H}_{13} \mathrm{BrNiS}_{2}$ & $\mathrm{C}_{10} \mathrm{H}_{13} \mathrm{BrPdS}_{2}$ & $\mathrm{C}_{10} \mathrm{H}_{13} \mathrm{BrPtS}_{2}$ & $\mathrm{C}_{20} \mathrm{H}_{17} \mathrm{BrPtS}_{2}$ & $\mathrm{C}_{10} \mathrm{H}_{13} \mathrm{ClPdS}_{2}$ \\
\hline fw & 335.94 & 383.63 & 472.32 & 596.46 & 339.17 \\
\hline crystal color & red & yellow & yellow & yellow & yellow \\
\hline $\begin{array}{l}\text { crystal system } \\
\text { space group }\end{array}$ & $\begin{array}{l}\text { monoclinic } \\
P 2_{1} / c(\text { no. } 14)\end{array}$ & $\begin{array}{l}\text { monoclinic } \\
\left.P 2_{1} / c \text { (no. } 14\right)\end{array}$ & $\begin{array}{l}\text { monoclinic } \\
P 2_{1} / c(\text { no. } 14)\end{array}$ & $\begin{array}{l}\text { monoclinic } \\
C 2 / c(\text { no. } 15)\end{array}$ & $\begin{array}{l}\text { monoclinic } \\
\left.P 2_{1} / c \text { (no. } 14\right)\end{array}$ \\
\hline$a[\AA]$ & $13.9357(2)$ & $8.9406(1)$ & $8.8451(7)$ & $15.2670(6)$ & $8.8210(1)$ \\
\hline$b[\AA]$ & $5.4349(1)$ & $33.1246(2)$ & $15.6207(9)$ & $11.6724(6)$ & $33.1239(2)$ \\
\hline$V\left[\AA^{3}\right]$ & $1182.69(3)$ & $3635.99(5)$ & $1209.42(17)$ & $3604.5(3)$ & $3567.02(5)$ \\
\hline$Z$ & 4 & 12 & 4 & 8 & 12 \\
\hline$D_{x}\left[\mathrm{~g} / \mathrm{cm}^{3}\right]$ & 1.887 & 2.102 & 2.594 & 2.198 & 1.895 \\
\hline$\mu\left[\mathrm{mm}^{-1}\right]$ & 5.329 & 5.131 & 15.210 & 10.233 & 2.094 \\
\hline abs. corr. method & analytical & multiscan & analytical & multiscan & multiscan \\
\hline abs. corr. range & $0.42-0.80$ & $0.41-0.54$ & $0.02-0.20$ & $0.57-1.00$ & $0.68-0.83$ \\
\hline$\rho_{\min / \max }\left[\mathrm{e} / \AA^{3}\right]$ & $-0.57 / 0.35$ & $-0.64 / 0.42$ & $-1.74 / 0.82$ & $-1.45 / 0.68$ & $-1.85 / 2.18$ \\
\hline
\end{tabular}

while stirring was continued for $2 \mathrm{~h}$. During the reaction, the initially light yellow colored solution became more intensely yellow colored when warmed to room temperature. The solvent was removed in vacuo and the product dissolved in benzene $(40 \mathrm{~mL})$ and filtrated through a short pad of Celite. The filtrated was concentrated to 5 $\mathrm{mL}$ and the product precipitated by adding hexanes as nonsolvent. The product was obtained as a yellow solid after removal of all volatiles in vacuo. Yield: $0.30 \mathrm{~g}(72 \%)$. Yellow crystals suitable for $\mathrm{X}$-ray diffraction were obtained by slow evaporation of a solution of the product in $\mathrm{CH}_{2} \mathrm{Cl}_{2} .{ }^{1} \mathrm{H}$ NMR $\left(300 \mathrm{MHz}, \mathrm{C}_{6} \mathrm{D}_{6}\right): \delta$ $6.86\left(\mathrm{t}, \mathrm{ArH}, 1 \mathrm{H},{ }^{3} J_{\mathrm{HH}}=7.5 \mathrm{~Hz}\right), 6.50\left(\mathrm{~d}, \mathrm{ArH}, 2 \mathrm{H},{ }^{3} J_{\mathrm{HH}}=7.2\right.$ $\mathrm{Hz}$ ), 3.26 (bs, $\left.\mathrm{CH}_{2} \mathrm{SMe}, 4 \mathrm{H}\right), 2.14$ (s, SMe, 6H). ${ }^{13} \mathrm{C}$ NMR $(75$ $\mathrm{MHz}, \mathrm{C}_{6} \mathrm{D}_{6}$ ): $\delta 155.59$ (s, ArCPd), 150.16, 124.98, 121.42 (s, ArC), $74.14\left(\mathrm{~s}, \mathrm{CH}_{2}\right), 51.64$ (s, SMe). Anal. Calcd for $\mathrm{C}_{10} \mathrm{H}_{13} \mathrm{BrNiS}_{2}$ : C, 35.75; H, 3.90; S, 19.09. Found: C, 35.71; H, 4.08; S, 19.07 .

$\left[\operatorname{PdBr}\left(\mathrm{C}_{6} \mathrm{H}_{2}\left(\mathrm{CH}_{2} \mathrm{SMe}\right)_{2}-\mathbf{2 , 6}\right)\right]$ (5). The palladium source $\left[\mathrm{Pd}_{2}-\right.$ $\left.\mathrm{dba}_{3}\right] \cdot \mathrm{CHCl}_{3}(0.39 \mathrm{~g}, 0.38 \mathrm{mmol})$ and $2(0.21 \mathrm{~g}, 0.76 \mathrm{mmol})$ were dissolved in benzene $(30 \mathrm{~mL})$ and the resulting dark-purple solution was stirred at room temperature for $16 \mathrm{~h}$. The solvent was removed in vacuo and the residue dissolved in $\mathrm{CH}_{2} \mathrm{Cl}_{2}(20 \mathrm{~mL})$ and subsequently filtrated through a short path of Celite. The yellow residue was concentrated to $3-5 \mathrm{~mL}$ and $\mathrm{Et}_{2} \mathrm{O}$ was added to precipitate the product. After a second precipitation from $\mathrm{CH}_{2} \mathrm{Cl}_{2}$ and drying in vacuo the product was obtained as a yellow solid. Yield: $0.20 \mathrm{~g}(69 \%)$. Yellow needle-shaped crystals suitable for $\mathrm{X}$-ray diffraction were obtained by slow diffusion of $\mathrm{Et}_{2} \mathrm{O}$ into a solution of $20 \mathrm{mg}$ of the product in $20 \mathrm{~mL} \mathrm{CH}_{2} \mathrm{Cl}_{2} .{ }^{1} \mathrm{H}$ NMR (300 $\left.\mathrm{MHz}, \mathrm{CDCl}_{3}\right): \delta 6.81\left(\mathrm{t}, \mathrm{ArH}, 1 \mathrm{H},{ }^{3} J_{\mathrm{HH}}=7.6 \mathrm{~Hz}\right), 6.56(\mathrm{~d}, \mathrm{ArH}$, $\left.2 \mathrm{H},{ }^{3} \mathrm{~J}_{\mathrm{HH}}=7.7 \mathrm{~Hz}\right), 3.47\left(\mathrm{bs}, \mathrm{CH}_{2} \mathrm{~S}, 2 \mathrm{H}\right), 3.24\left(\mathrm{bs}, \mathrm{CH}_{2} \mathrm{~S}, 2 \mathrm{H}\right)$, 2.24 (s, SMe, 6H) ${ }^{13} \mathrm{C} \mathrm{NMR}\left(\mathrm{CDCl}_{3}\right): \delta 162.76$ (bs, ArCPd), 148.74 (s, $\left.\mathrm{ArCCH}_{2}\right), 125.24,122.64$ (s, $\left.\mathrm{ArC}\right), 49.89\left(\mathrm{~s}, \mathrm{CH}_{2}\right), 23.67$ (s, SMe). Anal. Calcd for $\mathrm{C}_{10} \mathrm{H}_{13} \mathrm{BrPdS}_{2}$ : C, 31.31; H, 3.42; S, 16.72 . Found: C, 31.20; H, 3.50; S, 16.61.

$\left[\mathbf{P t B r}\left(\mathbf{C}_{6} \mathbf{H}_{2}\left(\mathbf{C H}_{2} \mathbf{S M e}\right)_{2}-\mathbf{2 , 6}\right)\right](\mathbf{6})$. To benzene $(30 \mathrm{~mL})$ was added the aryl bromide $2(0.21 \mathrm{~g}, 0.76 \mathrm{mmol})$ and $\left[\left\{\mathrm{Pt}(p \text {-tol })_{2}\left(\mu-\mathrm{SEt}_{2}\right)\right\}_{2}\right]$ $(0.36 \mathrm{~g}, 0.38 \mathrm{mmol})$. The white suspension was heated to reflux for $1 \mathrm{~h}$. The resulting yellowish clear solution was allowed to cool to room temperature and the volatiles were removed in vacuo. The residue was dissolved in $\mathrm{CH}_{2} \mathrm{Cl}_{2}(15 \mathrm{~mL})$ and filtrated through a short path of Celite. The filtrate was concentrated to $2-3 \mathrm{~mL}$ and $\mathrm{Et}_{2} \mathrm{O}(\sim 20 \mathrm{~mL})$ was slowly added to precipitate the product. The solid was collected and the precipitation repeated once more. The product was dried under reduced pressure and obtained as a yellowish solid. Yield: $0.16 \mathrm{~g}(76 \%)$. If necessary the product can be recrystallized from hot toluene. Yellow needle-shaped crystals suitable for X-ray diffraction were obtained by slow evaporation

of a $\mathrm{CH}_{2} \mathrm{Cl}_{2}$ solution. ${ }^{1} \mathrm{H}$ NMR $\left(300 \mathrm{MHz}, \mathrm{C}_{6} \mathrm{D}_{6}\right): \delta 6.89,6.88(\mathrm{t}$, $\left.\mathrm{ArH},{ }^{3} J_{\mathrm{HH}}=7.6 \mathrm{~Hz}, 1 \mathrm{H}\right), 6.63\left(\mathrm{~d}, \mathrm{ArH},{ }^{3} J_{\mathrm{HH}}=7.6 \mathrm{~Hz}, 2 \mathrm{H}\right), 3.73$ $\left(\mathrm{d}, \mathrm{CH}_{2},{ }^{2} J_{\mathrm{HH}}=15.7 \mathrm{~Hz},{ }^{3} J_{\mathrm{HPt}}=42.4 \mathrm{~Hz}, 2 \mathrm{H}\right), 3.69\left(\mathrm{~d}, \mathrm{CH}_{2},{ }^{2} J_{\mathrm{HH}}\right.$ $\left.=15.2 \mathrm{~Hz},{ }^{3} J_{\mathrm{HPt}}=31.38 \mathrm{~Hz}, 2 \mathrm{H}\right), 3.27\left(\mathrm{~d}, \mathrm{CH}_{2},{ }^{2} J_{\mathrm{HH}}=15.2 \mathrm{~Hz}\right.$, $\left.{ }^{3} J_{\mathrm{HPt}}=19.4 \mathrm{~Hz}, 2 \mathrm{H}\right), 3.15\left(\mathrm{~d}, \mathrm{CH}_{2},{ }^{2} J_{\mathrm{HH}}=15.7 \mathrm{~Hz},{ }^{3} J_{\mathrm{HPt}}=33.47\right.$ $\mathrm{Hz}, 2 \mathrm{H}), 2.25\left(\mathrm{t}, \mathrm{SMe},{ }^{3} J_{\mathrm{HPt}}=52.8 \mathrm{~Hz}, 6 \mathrm{H}\right), 2.18\left(\mathrm{t}, \mathrm{SMe},{ }^{3} J_{\mathrm{HPt}}=\right.$ $53.4 \mathrm{~Hz}, 6 \mathrm{H}) .{ }^{13} \mathrm{C} \mathrm{NMR}\left(\mathrm{CDCl}_{3}\right): \delta 152.41,152.17\left(\mathrm{~s}, \mathrm{ArC}_{\mathrm{ipso}}\right)$, $146.15\left(\mathrm{t}, \mathrm{ArC}_{\mathrm{ortho}},{ }^{2} J_{\mathrm{CPt}}=109.86 \mathrm{~Hz}\right), 124.53\left(\mathrm{~s}, \mathrm{ArC}_{\mathrm{para}}\right), 121.90$, $121.81\left(\mathrm{t}, \mathrm{ArC}_{\text {meta }},{ }^{3} J_{\mathrm{CPt}}=39.1 \mathrm{~Hz}\right), 52.24\left(\mathrm{t}, \mathrm{CH}_{2},{ }^{2} J_{\mathrm{CPt}}=34.2\right.$ $\mathrm{Hz}), 52.08\left(\mathrm{t}, \mathrm{CH}_{2},{ }^{2} J_{\mathrm{CPt}}=33.0 \mathrm{~Hz}\right), 24.96\left(\mathrm{t}, \mathrm{SMe},{ }^{2} J_{\mathrm{CPt}}=20.7\right.$ $\mathrm{Hz}), 24.45\left(\mathrm{t}, \mathrm{SMe},{ }^{2} J_{\mathrm{CPt}}=21.0 \mathrm{~Hz}\right) .{ }^{195} \mathrm{Pt}$ NMR (toluene- $\left.d_{8}\right): \delta$ -3967.36, -3980.18. Anal. Calcd for $\mathrm{C}_{10} \mathrm{H}_{13} \mathrm{BrPtS}_{2}$ : C, 25.43; H, 2.77; S, 13.58. Found: C, 25.54; H, 2.67; S, 13.67.

$\left[\mathbf{P d B r}\left(\mathrm{C}_{6} \mathbf{H}_{2}\left(\mathrm{CH}_{2} \mathrm{SPh}\right)_{2}-\mathbf{2 , 6}\right)\right](\mathbf{7})$. Solid $\left[\mathrm{Pd}_{2} \mathrm{dba}_{3}\right] \cdot \mathrm{CHCl}_{3}(0.29$ $\mathrm{g}, 0.28 \mathrm{mmol})$ was added to a solution of $\mathbf{3}(0.23 \mathrm{~g}, 0.57 \mathrm{mmol})$ in benzene $(20 \mathrm{~mL})$ and the resulting dark-purple solution was stirred for $16 \mathrm{~h}$ at room temperature. The solvent was removed under reduced pressure. The residue was dissolved in $\mathrm{CH}_{2} \mathrm{Cl}_{2}(20 \mathrm{~mL})$ and filtrated through a short pad of Celite. The yellow filtrate was concentrated to $2-3 \mathrm{~mL}$ and diethyl ether was slowly added to precipitate the product. The solid was collected, dissolved in $\mathrm{CH}_{2} \mathrm{Cl}_{2}$ $(2 \mathrm{~mL})$, and precipitated again until the mother liquor was nearly colorless. The product was dried in vacuo and obtained as a yellow solid. Yield: $0.21 \mathrm{~g}(71 \%)$. ${ }^{1} \mathrm{H}$ NMR $\left(300 \mathrm{MHz}, \mathrm{CDCl}_{3}\right): \delta 7.86$ (m, ArH, 4H), 7.38 (m, ArH, 6H), 6.96 (m, ArH, 3H), 4.63 (s, $\left.\mathrm{CH}_{2} \mathrm{~S}, 4 \mathrm{H}\right) .{ }^{13} \mathrm{C} \mathrm{NMR}\left(\mathrm{CDCl}_{3}\right): \delta 164.50(\mathrm{~s}, \mathrm{ArCPd}), 149.64(\mathrm{~s}$, $\mathrm{ArCCH}_{2}$ ), 132.63 (s, ArS), 131.77, 130.05, 129.82, 125.22, 122.29 (s, ArC), $52.83\left(\mathrm{~s}, \mathrm{CH}_{2}\right)$. Anal. Calcd for $\mathrm{C}_{20} \mathrm{H}_{17} \mathrm{BrPdS}_{2}$ : C, 47.30; H, 3.37; S, 12.63. Found: C, 47.30; H, 3.37; S, 12.72.

$\left[\operatorname{PtBr}\left(\mathrm{C}_{6} \mathrm{H}_{2}\left(\mathrm{CH}_{2} \mathrm{SPh}\right)_{2}-\mathbf{2 , 6}\right)\right](\mathbf{8})$. The pincer aryl halogen starting material $2(0.14 \mathrm{~g}, 0.36 \mathrm{mmol})$ and $\left[\left\{\mathrm{Pt}(p-\text { tol })_{2}\left(\mu-\mathrm{SEt}_{2}\right)\right\}_{2}\right](0.17 \mathrm{~g}$, $0.18 \mathrm{mmol}$ ) were added to benzene $(30 \mathrm{~mL})$, and the resulting white suspension was heated to reflux for $1 \mathrm{~h}$. The yellowish clear solution was allowed to cool to room temperature and the volatiles removed under reduced pressure. The residue was dissolved in $\mathrm{CH}_{2} \mathrm{Cl}_{2}(15$ $\mathrm{mL}$ ) and filtrated through a short pad of Celite. The filtrate was concentrated to $2-3 \mathrm{~mL}$ and $\mathrm{Et}_{2} \mathrm{O}$ was added slowly to precipitate the product. The solid was collected and the precipitation repeated once. The product was dried in vacuo and obtained as a yellowish solid. Yield: $0.16 \mathrm{~g}(76 \%)$. Yellow needle-shaped crystals suitable for $\mathrm{X}$-ray diffraction were obtained by slow evaporation of the solvent $\mathrm{CH}_{2} \mathrm{Cl}_{2} .{ }^{1} \mathrm{H}$ NMR (300 MHz, $\mathrm{CDCl}_{3}$ ): $\delta 7.81$ (m, $\mathrm{ArH}$, $4 \mathrm{H}), 7.37$ (m, ArH, 6H), 7.08 (m, ArH, 3H), 4.91 (bd, $\mathrm{CH}_{2} \mathrm{~S},{ }^{3} \mathrm{~J}_{\mathrm{HH}}$ $=29.8 \mathrm{~Hz}, 2 \mathrm{H}), 4.45\left(\mathrm{bd}, \mathrm{CH}_{2},{ }^{3} J_{\mathrm{HH}}=27.6 \mathrm{~Hz}, 2 \mathrm{H}\right) .{ }^{13} \mathrm{C} \mathrm{NMR}$ $\left(\mathrm{CDCl}_{3}\right)$ : 146.92, 132.67, (bs, $\left.\mathrm{ArC}\right), 132.67,130.57,129.72,124.54$ $(\mathrm{s}, \mathrm{ArC}), 121.37\left(\mathrm{~s},{ }^{2} J_{\mathrm{CPt}}=36.62 \mathrm{~Hz}\right), 56.05\left(\mathrm{bs}, \mathrm{CH}_{2}\right) .{ }^{195} \mathrm{Pt} \mathrm{NMR}$ 
(toluene- $d_{8}$ ): $\delta-3967.36,-4000.50$. Anal. Calcd for $\mathrm{C}_{20} \mathrm{H}_{17} \mathrm{BrPtS}_{2}$ : C, 40.21; H, 3.04; S, 10.73. Found: C, 40.08; H, 2.89; S, 10.79.

VT NMR Experiments. Saturated solutions of the various complexes $(4-\mathbf{8})$ were prepared in $0.5 \mathrm{~mL}$ toluene- $d_{8}$. An additional $0.1 \mathrm{~mL}$ toluene- $d_{8}$ was added to prevent precipitation at low temperatures. First, NMR spectra were recorded at $298 \mathrm{~K}$ on a Varian Inova 300 spectrometer. Next, VT NMR experiments were conducted: for each solution, ${ }^{1} \mathrm{H}$ NMR spectra were recorded at various temperatures, starting at the lowest temperature, and after each measurement the solution was slowly warmed up in steps of 10-20 K. Prior to each measurement, the sample was allowed to equilibrate for $15 \mathrm{~min}$ at that specific temperature. The temperature ranges used for each complex are as follows: 4 [ $\left.\mathrm{NiBr}\left({ }^{\mathrm{Me}} \mathrm{SCS}\right)\right]$ : 193-303 K, 5 [PdBr( $\left.\left.{ }^{\mathrm{Me}} \mathrm{SCS}\right)\right]: 203-373 \mathrm{~K}, 6\left[\mathrm{PtBr}\left({ }^{\mathrm{Me}} \mathrm{SCS}\right)\right]$ : 203-380 K, 7 [PdBr $\left.\left({ }^{\mathrm{Ph}} \mathrm{SCS}\right)\right]$ : $223-373 \mathrm{~K}$. Please note that below $230 \mathrm{~K}$ complex 7 started to precipitate, which gave poor NMR spectra. [PtBr $\left.\left({ }^{\mathrm{Ph}} \mathrm{SCS}\right)\right] \mathbf{8}(246-353 \mathrm{~K})$ already showed clear platinum satellites at the benzylic- $\mathrm{CH}_{2}$ signal (showing a sharp singlet) at $353 \mathrm{~K}\left({ }^{1} \mathrm{H} \mathrm{NMR}\left(300 \mathrm{MHz}\right.\right.$, toluene- $\left.d_{8}\right): \delta 4.00 \mathrm{ppm}(\mathrm{s}$, $\left.\mathrm{CH}_{2},{ }^{3} J_{\mathrm{HPt}}=36.4 \mathrm{~Hz}, 4 \mathrm{H}\right)$ ).

Crystal Structure Determinations. X-ray intensities were measured on a Nonius KappaCCD diffractometer with rotating anode and graphite monochromator $(\lambda=0.71073 \AA)$ at a temperature of $150(2) \mathrm{K}$ up to a resolution of $(\sin \theta / \lambda)_{\max }=0.65 \AA^{-1}$. The structures were solved with automated Patterson methods (program DIRDIF, ${ }^{37}$ compounds 4 and 5) or Direct Methods (program SHELXS-97, ${ }^{38}$ compounds $\mathbf{6}$ and 8). The initial coordinates for $\mathbf{9}$ were taken from the isostructural compound $\mathbf{5}$. Refinement was performed with SHELXL- $97^{38}$ on $F^{2}$ of all reflections. Non-hydrogen atoms were refined freely with anisotropic displacement parameters. In 4, all hydrogen atoms were located in the difference Fourier map; in all other structures hydrogen atoms were introduced in calculated positions. In all structures hydrogen atoms were refined as rigid groups. Geometry calculations, drawings and checks for higher symmetry were performed with the PLATON software package. ${ }^{39}$ Further crystallographic details are given in Table 4.

Acknowledgment. We kindly acknowledge NRSCCatalysis (HPD) and the Council for Chemical Sciences of The Netherlands Organisation for Scientific Research (CWNWO) (M.L., A.L.S.) for financial support.

OM800324W

(37) Beurskens, P. T.; Admiraal, G.; Beurskens, G.; Bosman, W. P.; Garcia-Granda, S.; Gould, R. O.; Smits, J. M. M.; Smykalla C. The DIRDIF99 program system; Technical Report of the Crystallography Laboratory at University of Nijmegen; University of Nijmegen: Nijmegen, The Netherlands, 1999.

(38) SHELXS-97: Program for crystal structure solution; Universität Göttingen: Göttingen, Germany, 1997.

(39) Spek, A. L. J. Appl. Crystallogr. 2003, 36, 7-13. 